\title{
,anc \\ Origin and Composition of Ferromanganese Deposits of New Caledonia Exclusive Economic Zone
}

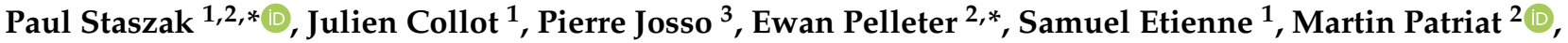 \\ Sandrine Cheron ${ }^{2}$, Audrey Boissier ${ }^{2}$ and Yaël Guyomard ${ }^{1}$
}

1 Geological Survey of New Caledonia, Direction de l'Industrie, des Mines et de l'Énergie de Nouvelle-Calédonie, BP M2, Nouméa 98845, New Caledonia; julien.collot@gouv.nc (J.C.); samuel.etienne@gouv.nc (S.E.); yael.guyomard@gouv.nc (Y.G.)

2 Institut Français de Recherche pour l'Exploitation de la Mer (IFREMER), Unité Géosciences Marines, 29280 Plouzané, France; martin.patriat@ifremer.fr (M.P.); sandrine.cheron@ifremer.fr (S.C.); audrey.boissier@ifremer.fr (A.B.)

3 British Geological Survey, Environmental Science Centre, Nottingham NG12 5GG, UK; piesso@bgs.ac.uk

* Correspondence: pl.staszak@laposte.net (P.S.); ewan.pelleter@ifremer.fr (E.P.)

check for

updates

Citation: Staszak, P.; Collot, J.; Josso, P.; Pelleter, E.; Etienne, S.; Patriat, M.; Cheron, S.; Boissier, A.; Guyomard, Y. Origin and Composition of Ferromanganese Deposits of New Caledonia Exclusive Economic Zone. Minerals 2022, 12, 255. https:// doi.org/10.3390/min12020255

Academic Editor: Francisco J. González

Received: 29 January 2022

Accepted: 10 February 2022

Published: 16 February 2022

Publisher's Note: MDPI stays neutral with regard to jurisdictional claims in published maps and institutional affiliations.

Copyright: (C) 2022 by the authors. Licensee MDPI, Basel, Switzerland. This article is an open access article distributed under the terms and conditions of the Creative Commons Attribution (CC BY) license (https:// creativecommons.org/licenses/by/ $4.0 /)$.

\begin{abstract}
Located in the South-West Pacific, at the northern extremity of the mostly submerged Zealandia continent, the New Caledonian Exclusive Economic Zone (EEZ) covers 1,470,000 km² and includes basins, ridges and seamounts where abundant ferromanganese crusts have been observed. Several investigations have been conducted since the 1970s on the nature and composition of ferromanganese crusts from New Caledonia's seamounts and ridges, but none have covered the entire EEZ. We present data from 104 ferromanganese crusts collected in New Caledonia's EEZ during twelve oceanographic cruises between 1974 and 2019. Samples were analysed for mineralogy, geochemical compositions, growth rates, and through a statistical approach using correlation coefficients and factor analysis. Crust thicknesses range from $1 \mathrm{~mm}$ to $115 \mathrm{~mm}$, with growth rates between $0.45 \mathrm{~mm} / \mathrm{Ma}$ and $102 \mathrm{~mm} / \mathrm{Ma}$. Based on textures, structures, discrimination plots, and growth rates, we distinguish a group of hydrogenetic crusts containing the highest mean contents of $\mathrm{Co}(0.42 \mathrm{wt} \%), \mathrm{Ni}(0.31 \mathrm{wt} \%)$, and high contents of $\mathrm{Mo}, \mathrm{V}, \mathrm{W}, \mathrm{Pb}, \mathrm{Zn}, \mathrm{Nb}$, from a group of hydrothermal and/or diagenetic deposits showing high mean contents of $\mathrm{Mn}(38.17 \mathrm{wt} \%)$, Ba $(0.56 \mathrm{wt} \%)$ and low contents of other trace metals. Several samples from this later group have exceptionally high content of $\mathrm{Ni}(0.7 \mathrm{wt} \%)$. The data shows that crusts from the southern part of the EEZ, notably seamounts of the Loyalty Ridge and the Lord Howe Rise, present high mineral potential for prospectivity owing to high contents of valuable metals, and constitute a great target for further investigation.
\end{abstract}

Keywords: ferromanganese crusts; New Caledonia; hydrogenetic; hydrothermal and diagenetic deposits

\section{Introduction}

Hydrogenetic ferromanganese (Fe-Mn) oxide deposits are known to be distributed widely in all oceans of the planet, the largest known fields being located in the Pacific Ocean [1]. They occur as crusts on sediment free surfaces like seamount flanks and summits, ridges, or any topographic reliefs located between 400 and $7000 \mathrm{~m}$ water depths [2,3]. Ferromanganese crusts grow by precipitation of metals from ambient cold seawater and accumulation on the seafloor, forming layers of Mn oxides and Fe-oxyhydroxides. Their thickness ranges from less than a millimeter up to $25 \mathrm{~cm}$ [4]. The hydrogenetic accumulation of Mn oxides and Fe-oxyhydroxides requires stable conditions over long periods of time (million years) to form thick crusts [5]. Their distribution, textures and composition are impacted by several parameters, such as surface bioproductivity, depth of the 
oxygen-minimum zone (OMZ), metal partitioning along the water column, bottom currents, proximity to land masses, and sedimentation rates [1]. The hydrogenetic accretion is believed to involve an inorganic colloidal-chemical mechanism, coupled to a surfacechemical mechanism [2]. Mn and $\mathrm{Fe}$, under normal physicochemical properties of seawater (Eh $>0.5 \mathrm{~V}$ and $\mathrm{pH} \pm 8,[6])$, are present in their oxidized form $\left(\mathrm{Mn}^{4+} \mathrm{O}_{2}\right.$ and $\mathrm{Fe}^{3+} \mathrm{OOH}$, respectively), and tends to form hydrated colloids $[7,8]$. These colloids generally have a positive or a negative surface that interacts with other colloids and dissolved hydrous metals ions [2]. Colloidal hydrous Mn oxide particles, with negatively charged surfaces, attract hydrated cations such as $\mathrm{Co}, \mathrm{Cu}, \mathrm{Zn}, \mathrm{Ni}, \mathrm{Tl}$, Ce or $\mathrm{Y}$, whilst slightly positively charged hydrous Fe-oxyhydroxide particles attract hydrated anions such as $\mathrm{Ti}, \mathrm{Zr}, \mathrm{Mo}, \mathrm{V}, \mathrm{Pb}, \mathrm{U}, \mathrm{Nb}$ or rare-earth elements (REE) [2,6]. Hydrogenetic Fe-Mn crusts precipitate at very slow rates (between 1 to $10 \mathrm{~mm} / \mathrm{Ma}$ ), allowing the adsorption and concentration of large quantities of metals on crust surfaces via the continuous interaction between oxides and seawater [1,2]. Compared to Earth's lithosphere, hydrogenetic Fe-Mn crusts are significantly enriched in several critical and rare metals such as $\mathrm{Bi}, \mathrm{Co}, \mathrm{Mo}, \mathrm{Nb}, \mathrm{Pt}, \mathrm{REE}, \mathrm{Te}, \mathrm{W}, \mathrm{Y}, \mathrm{Zr}$, which are critical to ensure the transition from a fossil-fuel-based energy system to a zero-carbon and renewable energy system [9]. Contrastingly, hydrothermal Fe-Mn-oxyhydroxide crusts form in the vicinity of high temperature hydrothermal systems, with supply from fall-out or precipitating directly from diffuse low temperature systems, showing starkly different morphologies and strongly fractionated compositions [10-14].

The first ferromanganese crusts collected in the vicinity of New Caledonia have been sampled between 1974 and 1976 during the GEORSTOM and EVA cruises. These crusts dredged from the flanks of New Caledonia's main island, Grande Terre, and the Loyalty Islands have been previously analysed and attest to their hydrogenetic origin with a mean Co content of $0.5 \%$ and a detrital enrichment [15-18]. Samples from the Loyalty Ridge seamounts were analysed in 2004, revealing hydrothermal deposits associated to a Miocene volcanic activity [19].

The present work provides a new set of data, combining analyses of deposits from recent and older cruises across the Exclusive Economic Zone (EEZ) of New Caledonia [20-30]. We report mineralogical and geochemical studies of 104 selected samples using analytical methods such as X-ray powder diffraction (XRD), X-ray fluorescence (XRF) and inductivelycoupled plasma mass spectrometry (ICP-MS), and discuss the nature, age and mineral associations of those Fe-Mn deposits. Factors controlling Fe-Mn crusts' composition and distribution within the New Caledonian EEZ are discussed. Finally, we conclude by presenting the most promising zone for further investigations in the vicinity of New Caledonia.

\section{Regional Settings}

New Caledonia is a French overseas territory located in the South-West Pacific Ocean, $2000 \mathrm{~km}$ east of Australia. Its EEZ and extended continental shelf cover an area of 1,470,000 km², and includes islands, continental and volcanic submarine ridges, an active subduction zone, ancient hotspots, and one of the largest ophiolitic complex on Earth [31-33]. The present-day physiography of the South-West Pacific results from a complex geological history, involving successive basin opening and closing since the Mesozoic fragmentation of the Gondwana supercontinent [34-36]. From West to East, several continental ridges are encountered: the Dampier Ridge, Lord Howe Rise, Fairway Ridge, and Norfolk Ridge (Figure 1). These are separated by the Fairway Basin, New Caledonia Trough, and South Loyalty Basin, all being part of the mostly submerged Zealandia continent (Figure 1A). The Pre-Mesozoic to Early Cretaceous rocks known onshore in New Caledonia, Australia and New Zealand attest for the presence of an ancient Andean-like subduction zone along Gondwana's eastern margin during much of the 260-110 Ma interval [37-39]. A change in tectonic regime, from convergence to extension, along Gondwana's eastern margin occurred at the end of the Early Cretaceous (110-100 Ma) and led to the break-up of Zealandia and Gondwana [40-42]. This extension phase ended during the Early Eocene and is marked by the end of oceanic seafloor spreading in the Tasman Sea and the development of a regional event known as TECTA (Tectonic Event 
of the Cenozoic in the Tasman Area) lasting until the Oligocene [43-45]. It is characterised by contractional deformation, basin formation and volcanism. It strongly impacted northern Zealandia, forming much of its present-day physiography, and ended with the obduction of sedimentary, mafic and ultramafic nappes in New Caledonia [31,46,47]. The origin of this event is likely related to a subduction initiation along Zealandia's eastern margin, of which the vergence and detailed chronology are debated [36]. Because of the lack of basement samples, the nature of the Loyalty Ridge remains unclear but is thought to be an Eocene to Miocene volcanic arc associated with this new subduction [48]. Other structures around New Caledonia, such as the Pines Ridge and the New Caledonia Trough, were also formed during this event $[31,49,50]$. The Neogene is characterised by extensional tectonics, causing the opening of the back-arc Norfolk and North Fiji basins [51]. Intense intraplate volcanism also affected the region during this period leading to the formation of the Lord Howe Seamounts Chain [52] (Figure 1B) and of numerous isolated guyots and seamounts [53-56]. The Middle Miocene is also the time when the North-East dipping Vanuatu subduction zone initiated along the Vitiaz Lineament and rolled back to its present-day position [36,57]. The subduction of the Australian plate under the Vanuatu Arch induces a flexure of the downgoing lithosphere and hence uplift and extensional tectonics as far as southern Grande Terre [58,59].

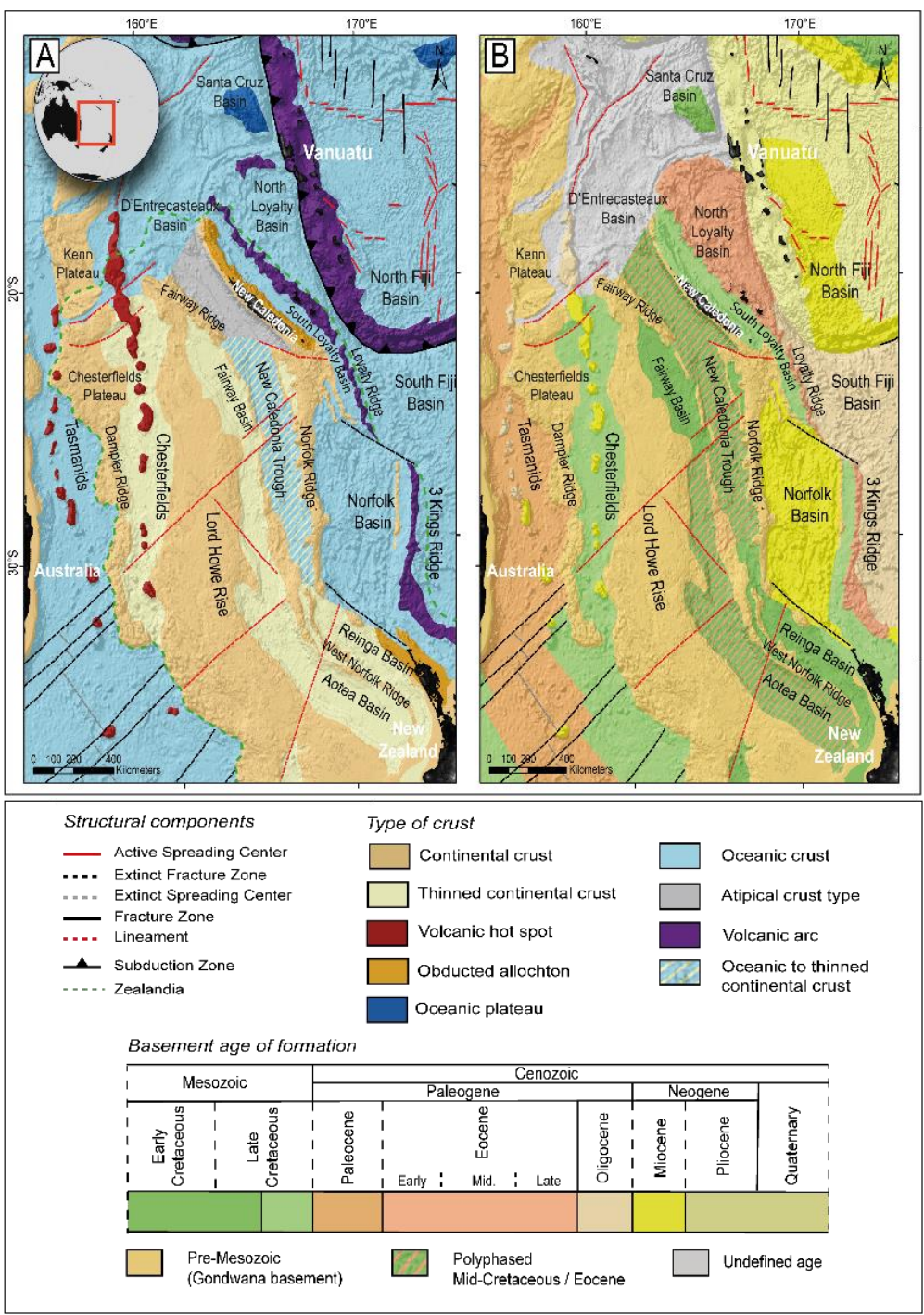

Figure 1. (A) Nature of basement of the South-West Pacific (modified after [33]); (B) Age of basement formation of the South-West Pacific (modified after [33]). 


\section{Material and Methods}

\subsection{Sample Collection}

A total of 104 samples of Fe-Mn deposits were selected from dredge material collected during multiple oceanographic cruises between 1974 and 2019 (Table 1). Samples were collected at different water depths ranging from $430 \mathrm{~m}$ to $4677 \mathrm{~m}$ (Figure 2). Samples from the Lord Howe seamount chain, Lord Howe Rise, Fairway Ridge, Norfolk Ridge, D'Entrecasteaux Basin, North D'Entrecasteaux Ridge and Loyalty Ridge were recovered in diverse settings with regard to depositional environments, age of structures, and nature of substrate rocks (Figure 1). For all crusts, a representative bulk sample of the whole stratigraphy has been selected. If any macroscopic boundaries were observed within the crust, representative subsamples of the macro-layers were taken, so that all the crust thickness was sampled. In such context, sub-samples are sorted in stratigraphic order. Table 1 shows the sampling type, thickness, location, depth, cruise and substrate rock (vacuolar to amygdaloidal basalt, andesite, hyaloclastite breccia, shoshonite, polygenic breccia, bioclastic limestone, or mudstone). A large proportion of crusts were lacking substrate rocks.

Table 1. Sample information for selected deposits $(n=104)$.

\begin{tabular}{|c|c|c|c|c|c|c|c|}
\hline Samples & Type & $\begin{array}{c}\text { Avg Crusts } \\
\text { Thickness (mm) }\end{array}$ & Latitude (S) & $\begin{array}{l}\text { Longitude } \\
\text { (E) }\end{array}$ & $\begin{array}{l}\text { Water Depth } \\
\text { (m) }\end{array}$ & Cruise & $\begin{array}{l}\text { Simplified } \\
\text { Substrate }\end{array}$ \\
\hline DW772 & Bulk & 5 & $26^{\circ} 46^{\prime} 59.88^{\prime \prime}$ & $170^{\circ} 22^{\prime} 1.21^{\prime \prime}$ & 902 & BATHUS3 & - \\
\hline DW774 & Bulk & 2 & $26^{\circ} 48^{\prime}$ & $170^{\circ} 22^{\prime} 1.21^{\prime \prime}$ & 925 & BATHUS3 & Volcanics \\
\hline DW778B & Bulk & - & $25^{\circ} 16^{\prime} 59.88^{\prime \prime}$ & $170^{\circ} 7^{\prime} 1.21^{\prime \prime}$ & 755 & BATHUS3 & - \\
\hline DW778D & Bulk & - & $25^{\circ} 16^{\prime} 59.88^{\prime \prime}$ & $170^{\circ} 7^{\prime} 1.21^{\prime \prime}$ & 755 & BATHUS3 & - \\
\hline DW778D2 & Bulk & - & $25^{\circ} 16^{\prime} 59.88^{\prime \prime}$ & $170^{\circ} 7^{\prime} 1.21^{\prime \prime}$ & 755 & BATHUS3 & - \\
\hline DW2482 & Bulk & - & $24^{\circ} 8^{\prime} 39.01^{\prime \prime}$ & $161^{\circ} 43^{\prime} 5.99^{\prime \prime}$ & 430 & EBISCO & - \\
\hline DR11Ai & Bulk & 97 & $18^{\circ} 0^{\prime} 58.68^{\prime \prime}$ & $160^{\circ} 43^{\prime} 42.6^{\prime \prime}$ & 2375 & ECOSAT & - \\
\hline DR11Ai-1 & Layers & $0-40$ & $18^{\circ} 0^{\prime} 58.68^{\prime \prime}$ & $160^{\circ} 43^{\prime} 42.6^{\prime \prime}$ & 2375 & ECOSAT & - \\
\hline DR11Ai-2 & Layers & $40-50$ & $18^{\circ} 0^{\prime} 58.68^{\prime \prime}$ & $160^{\circ} 43^{\prime} 42.6^{\prime \prime}$ & 2375 & ECOSAT & - \\
\hline DR11Ai-3 & Layers & $50-80$ & $18^{\circ} 0^{\prime} 58.68^{\prime \prime}$ & $160^{\circ} 43^{\prime} 42.6^{\prime \prime}$ & 2375 & ECOSAT & - \\
\hline DR11Ai-4 & Layers & $80-97$ & $18^{\circ} 0^{\prime} 58.68^{\prime \prime}$ & $160^{\circ} 43^{\prime} 42.6^{\prime \prime}$ & 2375 & ECOSAT & - \\
\hline DR13Bii & Bulk & 30 & $17^{\circ} 21^{\prime} 37.44^{\prime \prime}$ & $158^{\circ} 50^{\prime} 8.16^{\prime \prime}$ & 1765 & ECOSAT & - \\
\hline DR14H & Bulk & 10 & $18^{\circ} 55^{\prime} 28.2^{\prime \prime}$ & $159^{\circ} 11^{\prime} 56.76^{\prime \prime}$ & 2900 & ECOSAT & Volcanics \\
\hline DR15A & Bulk & 2 & $18^{\circ} 18^{\prime} 36.72^{\prime \prime}$ & $158^{\circ} 28^{\prime} 17.04^{\prime \prime}$ & 2225 & ECOSAT & Limestone \\
\hline DR18F & Bulk & 14 & $20^{\circ} 5^{\prime} 3.12^{\prime \prime}$ & $160^{\circ} 11^{\prime} 32.64^{\prime \prime}$ & 1150 & ECOSAT & - \\
\hline E-DR08B & Bulk & 60 & $18^{\circ} 25^{\prime} 8.04^{\prime \prime}$ & $164^{\circ} 0^{\prime} 28.44^{\prime \prime}$ & 1400 & ECOSAT & - \\
\hline E-DR08B-1 & Layers & $0-20$ & $18^{\circ} 25^{\prime} 8.04^{\prime \prime}$ & $164^{\circ} 0^{\prime} 28.44^{\prime \prime}$ & 1400 & ECOSAT & - \\
\hline E-DR08B-2 & Layers & $20-40$ & $18^{\circ} 25^{\prime} 8.04^{\prime \prime}$ & $164^{\circ} 0^{\prime} 28.44^{\prime \prime}$ & 1400 & ECOSAT & - \\
\hline E-DR08B-3 & Layers & $40-60$ & $18^{\circ} 25^{\prime} 8.04^{\prime \prime}$ & $164^{\circ} 0^{\prime} 28.44^{\prime \prime}$ & 1400 & ECOSAT & - \\
\hline DR48-021 & Bulk & 44 & $17^{\circ} 53^{\prime} 38^{\prime \prime}$ & $159^{\circ} 15^{\prime} 11^{\prime \prime}$ & 2060 & ECOSAT3 & - \\
\hline DR53-008 & Bulk & 31 & $23^{\circ} 14^{\prime} 31^{\prime \prime}$ & $159^{\circ} 46^{\prime} 11^{\prime \prime}$ & 1390 & ECOSAT3 & - \\
\hline DR54-009 & Bulk & 8 & $24^{\circ} 39^{\prime} 6^{\prime \prime}$ & $159^{\circ} 42^{\prime} 57^{\prime \prime}$ & 1350 & ECOSAT3 & Volcanics \\
\hline $102 \mathrm{D}$ & Bulk & - & $18^{\circ} 38^{\prime} 24^{\prime \prime}$ & $163^{\circ} 31^{\prime} 29.97^{\prime \prime}$ & 2644 & EVA & - \\
\hline $105 \mathrm{D}$ & Bulk & - & $18^{\circ} 20^{\prime} 6^{\prime \prime}$ & $163^{\circ} 58^{\prime} 1.18^{\prime \prime}$ & 1467 & EVA & - \\
\hline $108 \mathrm{D}$ & Bulk & - & $19^{\circ} 31^{\prime} 45.48^{\prime \prime}$ & $164^{\circ} 11^{\prime} 56.42^{\prime \prime}$ & 2954 & EVA & - \\
\hline 109D & Bulk & - & $20^{\circ} 30^{\prime} 18^{\prime \prime}$ & $165^{\circ} 13^{\prime} 37.22^{\prime \prime}$ & 2245 & EVA & - \\
\hline $110 \mathrm{D}$ & Bulk & 34 & $20^{\circ} 33^{\prime} 18^{\prime \prime}$ & $165^{\circ} 19^{\prime} 8.4^{\prime \prime}$ & 2100 & EVA & - \\
\hline $113 \mathrm{D}$ & Bulk & 11 & $21^{\circ} 22^{\prime} 14.88^{\prime \prime}$ & $166^{\circ} 50^{\prime} 31.18^{\prime \prime}$ & 1200 & EVA & Breccia \\
\hline $114 \mathrm{D}$ & Bulk & 3 & $21^{\circ} 36^{\prime} 11.88^{\prime \prime}$ & $166^{\circ} 51^{\prime} 50.39^{\prime \prime}$ & 1185 & EVA & Limestone \\
\hline $116 \mathrm{D}$ & Bulk & 25 & $21^{\circ} 14^{\prime} 6^{\prime \prime}$ & $167^{\circ} 29^{\prime} 49.18^{\prime \prime}$ & 2210 & EVA & Breccia \\
\hline 117D & Bulk & 30 & $24^{\circ} 43^{\prime} 59.88^{\prime \prime}$ & $169^{\circ} 25^{\prime} 30.01^{\prime \prime}$ & 1800 & EVA & Limestone \\
\hline GO14D & Bulk & 14 & $24^{\circ} 28^{\prime} 0.12^{\prime \prime}$ & $168^{\circ} 49^{\prime} 58.77^{\prime \prime}$ & 1450 & GEORSTOM1 & Breccia \\
\hline GO15D & Bulk & 5 & $24^{\circ} 27^{\prime} 42.12^{\prime \prime}$ & $168^{\circ} 51^{\prime} 25.18^{\prime \prime}$ & 1325 & GEORSTOM1 & Mudstone \\
\hline GO16D & Bulk & 6 & $24^{\circ} 22^{\prime} 59.88^{\prime \prime}$ & $168^{\circ} 50^{\prime} 31.18^{\prime \prime}$ & 1240 & GEORSTOM1 & Mudstone \\
\hline GO18D & Bulk & 16 & $24^{\circ} 18^{\prime} 54^{\prime \prime}$ & $168^{\circ} 14^{\prime} 16.82^{\prime \prime}$ & 585 & GEORSTOM1 & Limestone \\
\hline GO20D & Bulk & 2 & $25^{\circ} 55^{\prime} 23.88^{\prime \prime}$ & $168^{\circ} 0^{\prime} 28.78^{\prime \prime}$ & 1220 & GEORSTOM1 & Sandstone \\
\hline GO3D & Bulk & 38 & $23^{\circ} 28^{\prime} 0.12^{\prime \prime}$ & $167^{\circ} 58^{\prime} 4.81^{\prime \prime}$ & 2100 & GEORSTOM1 & Breccia \\
\hline GO202 & Bulk & 57 & $19^{\circ} 56^{\prime} 53.88^{\prime \prime}$ & $160^{\circ} 48^{\prime} 10.77^{\prime \prime}$ & 2425 & GEORSTOM2 & - \\
\hline
\end{tabular}


Table 1. Cont.

\begin{tabular}{|c|c|c|c|c|c|c|c|}
\hline Samples & Type & $\begin{array}{c}\text { Avg Crusts } \\
\text { Thickness (mm) }\end{array}$ & Latitude (S) & $\begin{array}{l}\text { Longitude } \\
\text { (E) }\end{array}$ & $\begin{array}{l}\text { Water Depth } \\
\text { (m) }\end{array}$ & Cruise & $\begin{array}{c}\text { Simplified } \\
\text { Substrate }\end{array}$ \\
\hline GO209 & Bulk & 42 & $18^{\circ} 31^{\prime} 59.88^{\prime \prime}$ & $163^{\circ} 37^{\prime} 58.78^{\prime \prime}$ & 1310 & GEORSTOM2 & - \\
\hline GO302D & Bulk & 40 & $13^{\circ} 57^{\prime} 14.4^{\prime \prime}$ & $158^{\circ} 13^{\prime} 40.8^{\prime \prime}$ & 2190 & GEORSTOM3 & - \\
\hline GO327D & Bulk & 115 & $20^{\circ} 5^{\prime} 48.12^{\prime \prime}$ & $164^{\circ} 45^{\prime} 25.21^{\prime \prime}$ & 1820 & GEORSTOM3 & - \\
\hline GO302D-1 & Layers & $0-10$ & $13^{\circ} 57^{\prime} 14.4^{\prime \prime}$ & $158^{\circ} 13^{\prime} 40.8^{\prime \prime}$ & 2190 & GEORSTOM3 & - \\
\hline GO302D-2 & Layers & $10-40$ & $13^{\circ} 57^{\prime} 14.4^{\prime \prime}$ & $158^{\circ} 13^{\prime} 40.8^{\prime \prime}$ & déc-05 & GEORSTOM3 & - \\
\hline GO310 & Bulk & 43 & $13^{\circ} 58^{\prime} 18.48^{\prime \prime}$ & $162^{\circ} 43^{\prime} 35.76^{\prime \prime}$ & 3375 & GEORSTOM3 & - \\
\hline GO314D10 & Bulk & - & $16^{\circ} 27^{\prime}$ & $165^{\circ} 1^{\prime} 19.21^{\prime \prime}$ & 3513 & GEORSTOM3 & - \\
\hline GO316D31 & Bulk & - & $16^{\circ} 34^{\prime} 0.12^{\prime \prime}$ & $164^{\circ} 33^{\prime} 10.77^{\prime \prime}$ & 3147 & GEORSTOM3 & - \\
\hline GO350-D6 & Bulk & 33 & $33^{\circ} 38^{\prime} 52^{\prime \prime}$ & $169^{\circ} 8^{\prime} 5^{\prime \prime}$ & 2500 & GEORSTOM3 & Sandstone \\
\hline GO317D10 & Bulk & - & $16^{\circ} 26^{\prime} 35.88^{\prime \prime}$ & $164^{\circ} 25^{\prime} 47.97^{\prime \prime}$ & 3311 & GEORSTOM3 & - \\
\hline GO320 & Bulk & 6 & $16^{\circ} 7^{\prime} 54.12^{\prime \prime}$ & $163^{\circ} 20^{\prime} 49.2^{\prime \prime}$ & 4150 & GEORSTOM3 & - \\
\hline GO321D2 & Bulk & - & $17^{\circ} 36^{\prime} 29.88^{\prime \prime}$ & $163^{\circ} 17^{\prime} 41.99^{\prime \prime}$ & 4677 & GEORSTOM3 & - \\
\hline GO322D4 & Bulk & - & $17^{\circ} 46^{\prime} 30^{\prime \prime}$ & $163^{\circ} 8^{\prime} 52.78^{\prime \prime}$ & 4336 & GEORSTOM3 & - \\
\hline GO323D4 & Bulk & - & $16^{\circ} 4^{\prime} 30^{\prime \prime}$ & $163^{\circ} 24^{\prime} 7.17^{\prime \prime}$ & 4493 & GEORSTOM3 & - \\
\hline GO325D2 & Bulk & - & $18^{\circ} 54^{\prime} 29.88^{\prime \prime}$ & $163^{\circ} 1^{\prime} 22.78^{\prime \prime}$ & 4019 & GEORSTOM3 & - \\
\hline GO327D-1 & Layers & $0-25$ & $20^{\circ} 5^{\prime} 48.12^{\prime \prime}$ & $164^{\circ} 45^{\prime} 25.21^{\prime \prime}$ & 1820 & GEORSTOM3 & - \\
\hline GO327D-2 & Layers & $25-65$ & $20^{\circ} 5^{\prime} 48.12^{\prime \prime}$ & $164^{\circ} 45^{\prime} 25.21^{\prime \prime}$ & 1820 & GEORSTOM3 & - \\
\hline GO327D-3 & Layers & 65-105 & $20^{\circ} 5^{\prime} 48.12^{\prime \prime}$ & $164^{\circ} 45^{\prime} 25.21^{\prime \prime}$ & 1820 & GEORSTOM3 & - \\
\hline GO327D-4 & Layers & $105-115$ & $20^{\circ} 5^{\prime} 48.12^{\prime \prime}$ & $164^{\circ} 45^{\prime} 25.21^{\prime \prime}$ & 1820 & GEORSTOM3 & - \\
\hline GO338D2 & Bulk & - & $23^{\circ} 57^{\prime} 42.12^{\prime \prime}$ & $167^{\circ} 18^{\prime} 0.01^{\prime \prime}$ & 226,500 & GEORSTOM3 & - \\
\hline GO347D & Bulk & - & $31^{\circ} 31^{\prime} 55^{\prime \prime}$ & $168^{\circ} 5^{\prime} 4^{\prime \prime}$ & 2416 & GEORSTOM3 & - \\
\hline GO348D6 & Bulk & 10 & $31^{\circ} 52^{\prime} 58^{\prime \prime}$ & $167^{\circ} 29^{\prime} 8^{\prime \prime}$ & 1150 & GEORSTOM3 & Sandstone \\
\hline GO350-D6-1 & Layers & $0-20$ & $33^{\circ} 38^{\prime} 52^{\prime \prime}$ & $169^{\circ} 8^{\prime} 5^{\prime \prime}$ & 2500 & GEORSTOM3 & Sandstone \\
\hline GO350-D6-2 & Layers & $20-30$ & $33^{\circ} 38^{\prime} 52^{\prime \prime}$ & $169^{\circ} 8^{\prime} 5^{\prime \prime}$ & 2500 & GEORSTOM3 & Sandstone \\
\hline GO350-D6-3 & Layers & $30-33$ & $33^{\circ} 38^{\prime} 52^{\prime \prime}$ & $169^{\circ} 8^{\prime} 5^{\prime \prime}$ & 2500 & GEORSTOM3 & Sandstone \\
\hline DR06B & Bulk & 4 & $22^{\circ} 33^{\prime} 11.76^{\prime \prime}$ & $164^{\circ} 55^{\prime} 23.22^{\prime \prime}$ & 878 & IPOD & Limestone \\
\hline DW4998D & Bulk & - & $24^{\circ} 10^{\prime} 24^{\prime \prime}$ & $161^{\circ} 43^{\prime} 24^{\prime \prime}$ & 650 & KANADEEP & - \\
\hline DW4998E & Bulk & - & $24^{\circ} 10^{\prime} 24^{\prime \prime}$ & $161^{\circ} 43^{\prime} 24^{\prime \prime}$ & 650 & KANADEEP & - \\
\hline CР5069 & Bulk & 9 & $24^{\circ} 22^{\prime} 15.38^{\prime \prime}$ & $169^{\circ} 35^{\prime} 20.65^{\prime \prime}$ & 1118 & KANADEEP2 & Limestone \\
\hline DN5064 & Bulk & 14 & $24^{\circ} 49^{\prime} 1.92^{\prime \prime}$ & $169^{\circ} 24^{\prime} 59.58^{\prime \prime}$ & 1023 & KANADEEP2 & Breccia \\
\hline DN5079 & Bulk & 47 & $25^{\circ} 31^{\prime} 51.31^{\prime \prime}$ & $169^{\circ} 9^{\prime} 28.58^{\prime \prime}$ & 2038 & KANADEEP2 & Sandstone \\
\hline DN5080B & Bulk & 9 & $25^{\circ} 32^{\prime} 21.19^{\prime \prime}$ & $169^{\circ} 1^{\prime} 55.56^{\prime \prime}$ & 1591 & KANADEEP2 & Breccia \\
\hline DN5085A & Bulk & 23 & $25^{\circ} 38^{\prime} 18.28^{\prime \prime}$ & $168^{\circ} 21^{\prime} 22.61^{\prime \prime}$ & 1606 & KANADEEP2 & - \\
\hline DW5067B & Bulk & 28 & $24^{\circ} 28^{\prime} 8.15^{\prime \prime}$ & $169^{\circ} 36^{\prime} 48.96^{\prime \prime}$ & 864 & KANADEEP2 & LImestone \\
\hline DW5070A & Bulk & 19 & $24^{\circ} 15^{\prime} 57.67^{\prime \prime}$ & $169^{\circ} 37^{\prime} 45.98^{\prime \prime}$ & 1709 & KANADEEP2 & Volcanics \\
\hline DW5073 & Bulk & 12 & $24^{\circ} 16^{\prime} 33.6^{\prime \prime}$ & $169^{\circ} 51^{\prime} 45.14^{\prime \prime}$ & 796 & KANADEEP2 & Limestone \\
\hline DW5086B & Bulk & 22 & $25^{\circ} 38^{\prime} 57.73^{\prime \prime}$ & $168^{\circ} 22^{\prime} 26.87^{\prime \prime}$ & 1540 & KANADEEP2 & - \\
\hline DW5087 & Bulk & 17 & $25^{\circ} 38^{\prime} 26.34^{\prime \prime}$ & $168^{\circ} 25^{\prime} 3.61^{\prime \prime}$ & 1680 & KANADEEP2 & Limestone \\
\hline DW5089B & Bulk & 8 & $24^{\circ} 24^{\prime} 37.12^{\prime \prime}$ & $168^{\circ} 50^{\prime} 47.54^{\prime \prime}$ & 1393 & KANADEEP2 & Volcanics \\
\hline DW5090B & Bulk & 3 & $24^{\circ} 25^{\prime} 8.76^{\prime \prime}$ & $168^{\circ} 48^{\prime} 14.47^{\prime \prime}$ & 1328 & KANADEEP2 & Limestone \\
\hline DW5091A & Bulk & 6 & $24^{\circ} 26^{\prime} 54.2^{\prime \prime}$ & $168^{\circ} 50^{\prime} 59.1^{\prime \prime}$ & 1582 & KANADEEP2 & Sandstone \\
\hline DR01A & Bulk & 4 & $25^{\circ} 47^{\prime} 17.52^{\prime \prime}$ & $166^{\circ} 58^{\prime} 14.52^{\prime \prime}$ & 1115 & VESPA & Volcanics \\
\hline DR04C & Bulk & 54 & $28^{\circ} 23^{\prime} 29.04^{\prime \prime}$ & $167^{\circ} 8^{\prime} 52.44^{\prime \prime}$ & 2321 & VESPA & - \\
\hline DR07B & Bulk & 27 & $29^{\circ} 41^{\prime} 53.52^{\prime \prime}$ & $167^{\circ} 14^{\prime} 26.52^{\prime \prime}$ & 1569 & VESPA & Breccia \\
\hline DR08C & Bulk & 55 & $25^{\circ} 3^{\prime} 42.84^{\prime \prime}$ & $170^{\circ} 19^{\prime} 34.68^{\prime \prime}$ & 2271 & VESPA & Volcanics \\
\hline DR10B & Bulk & 40 & $26^{\circ} 50^{\prime} 55.32^{\prime \prime}$ & $170^{\circ} 19^{\prime} 9.12^{\prime \prime}$ & 1523 & VESPA & Limestone \\
\hline DR14F & Bulk & 60 & $26^{\circ} 25^{\prime} 17.04^{\prime \prime}$ & $169^{\circ} 41^{\prime} 48.12^{\prime \prime}$ & 2112 & VESPA & Breccia \\
\hline DR13Ci & Bulk & 24 & $26^{\circ} 19^{\prime} 54.84^{\prime \prime}$ & $169^{\circ} 32^{\prime} 55.68^{\prime \prime}$ & 2731 & VESPA & Breccia \\
\hline DR13D & Bulk & 15 & $26^{\circ} 19^{\prime} 54.84^{\prime \prime}$ & $169^{\circ} 32^{\prime} 55.68^{\prime \prime}$ & 2731 & VESPA & Breccia \\
\hline DR14F-1 & Layers & $0-35$ & $26^{\circ} 25^{\prime} 17.04^{\prime \prime}$ & $169^{\circ} 41^{\prime} 48.12^{\prime \prime}$ & 2112 & VESPA & Breccia \\
\hline DR19K & Bulk & 58 & $27^{\circ} 50^{\prime} 49.56^{\prime \prime}$ & $170^{\circ} 28^{\prime} 5.88^{\prime \prime}$ & 3028 & VESPA & Breccia \\
\hline DR14F-2 & Layers & $35-60$ & $26^{\circ} 25^{\prime} 17.04^{\prime \prime}$ & $169^{\circ} 41^{\prime} 48.12^{\prime \prime}$ & 2112 & VESPA & Breccia \\
\hline DR21F & Bulk & 50 & $27^{\circ} 29^{\prime} 52.44^{\prime \prime}$ & $171^{\circ} 25^{\prime} 42.24^{\prime \prime}$ & 3385 & VESPA & Breccia \\
\hline DR19K-1 & Layers & $0-25$ & $27^{\circ} 50^{\prime} 49.56^{\prime \prime}$ & $170^{\circ} 28^{\prime} 5.88^{\prime \prime}$ & 3028 & VESPA & Breccia \\
\hline DR19K-2 & Layers & $25-60$ & $27^{\circ} 50^{\prime} 49.56^{\prime \prime}$ & $170^{\circ} 28^{\prime} 5.88^{\prime \prime}$ & 3028 & VESPA & Volcanics \\
\hline DR21Biii & Bulk & 16 & $27^{\circ} 29^{\prime} 52.44^{\prime \prime}$ & $171^{\circ} 25^{\prime} 42.24^{\prime \prime}$ & 3385 & VESPA & - \\
\hline
\end{tabular}


Table 1. Cont.

\begin{tabular}{cccccccc}
\hline Samples & Type & $\begin{array}{c}\text { Avg Crusts } \\
\text { Thickness }(\mathbf{m m})\end{array}$ & Latitude (S) & $\begin{array}{c}\text { Longitude } \\
\mathbf{( E )}\end{array}$ & $\begin{array}{c}\text { Water Depth } \\
(\mathbf{m})\end{array}$ & $\begin{array}{c}\text { Simplified } \\
\text { Substrate }\end{array}$ \\
\hline DR38C & Bulk & 35 & $28^{\circ} 33^{\prime} 56.16^{\prime \prime}$ & $172^{\circ} 43^{\prime} 21^{\prime \prime}$ & 2072 & VESPA \\
DR21F-1 & Layers & $0-30$ & $27^{\circ} 29^{\prime} 52.44^{\prime \prime}$ & $171^{\circ} 25^{\prime} 42.24^{\prime \prime}$ & 3385 & VESPA & - \\
DR21F-2 & Layers & $30-50$ & $27^{\circ} 29^{\prime} 52.44^{\prime \prime}$ & $171^{\circ} 25^{\prime} 42.24^{\prime \prime}$ & 3385 & VESPA & Volcanics \\
DR22A & Bulk & 13 & $27^{\circ} 18^{\prime} 48.6^{\prime \prime}$ & $171^{\circ} 55^{\prime} 37.56^{\prime \prime}$ & 2849 & VESPA \\
DR29F & Bulk & 27 & $28^{\circ} 38^{\prime} 18.6^{\prime \prime}$ & $172^{\circ} 2^{\prime} 0.96^{\prime \prime}$ & 2145 & VESPA & - \\
DR38C-1 & Layers & $0-25$ & $28^{\circ} 33^{\prime} 56.16^{\prime \prime}$ & $172^{\circ} 43^{\prime} 21^{\prime \prime}$ & 2072 & VESPA & - \\
DR38C-2 & Layers & $25-35$ & $28^{\circ} 33^{\prime} 56.16^{\prime \prime}$ & $172^{\circ} 43^{\prime} 21^{\prime \prime}$ & 2072 & VESPA & - \\
DR41Ai & Bulk & 8 & $25^{\circ} 44^{\prime} 1.32^{\prime \prime}$ & $170^{\circ} 4^{\prime} 0.84^{\prime \prime}$ & 2861 & VESPA & Volcanics \\
DR42B & Bulk & 20 & $24^{\circ} 12^{\prime} 37.08^{\prime \prime}$ & $167^{\circ} 8^{\prime} 24.36^{\prime \prime}$ & 1145 & VESPA & Limestone \\
V-DR08B & Bulk & 52 & $25^{\circ} 3^{\prime} 42.84^{\prime \prime}$ & $170^{\circ} 19^{\prime} 34.68^{\prime \prime}$ & 2271 & VESPA & Hyaloclastite \\
\hline
\end{tabular}

Symbol "-" means that there is no thickness information for the sample; Crusts with no substrate are marked as "-".

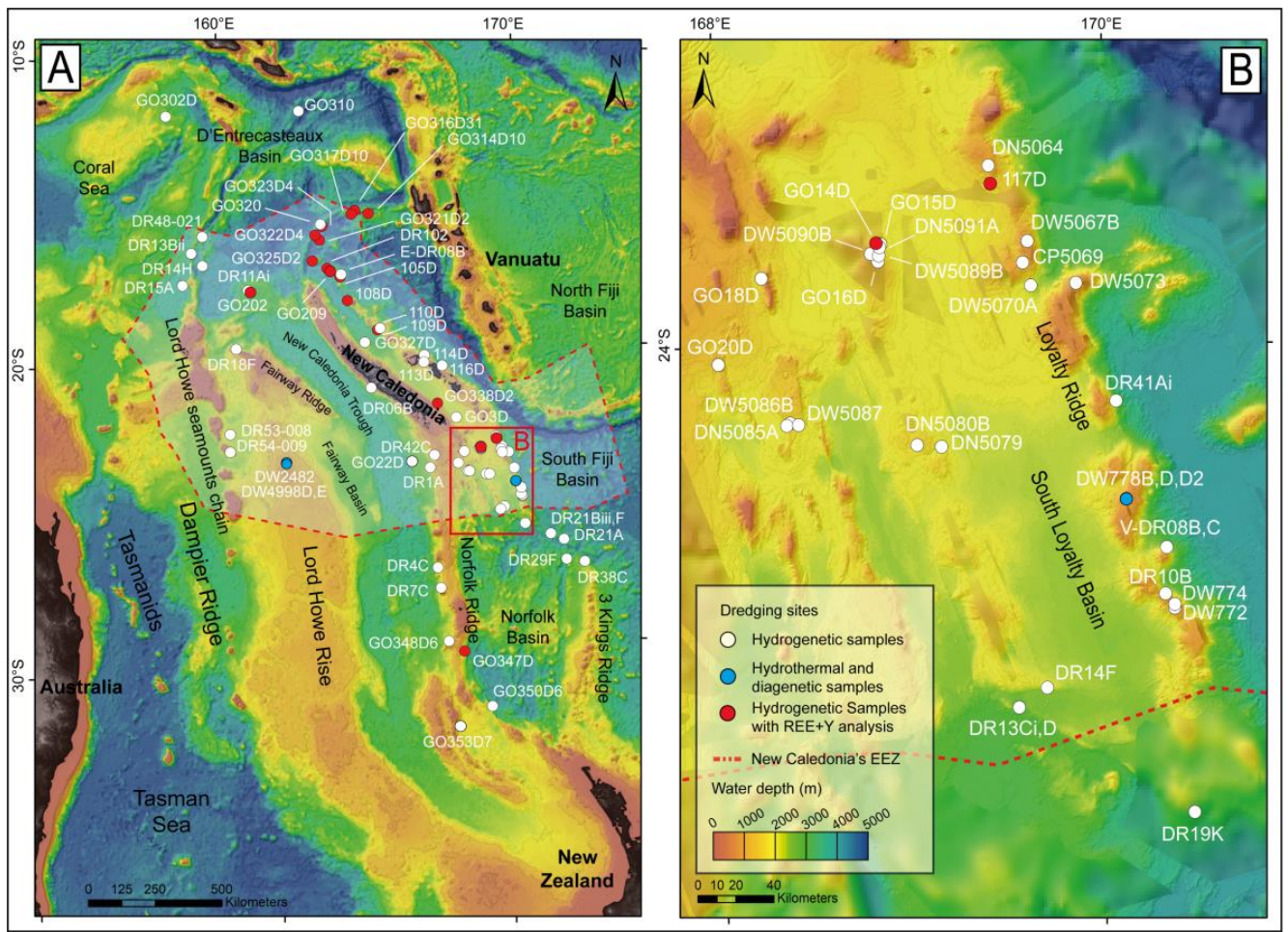

Figure 2. (A) Bathymetric map of the South-West Pacific; (B) Bathymetric map of southern New Caledonia.

\subsection{Mineralogical Analyses}

X-ray diffraction (XRD) analyses were conducted with a BRUKER AXS D8 Advance diffractometer. Samples were top loaded into $2.5 \mathrm{~cm}$ diameter circular cavity holders, and all analyses were run between $5^{\circ}$ and $70^{\circ} 2 \theta$, with $0.01^{\circ} 2 \theta$ step at $1 \mathrm{~s} /$ step (monochromatic $\mathrm{Cu}$ $\mathrm{K} \alpha$ radiation, $40 \mathrm{kV}, 30 \mathrm{~mA}$ ). Minerals were identified using the Diffrac.Suite EVA software. This methodology allows the quick identification of most minerals (e.g., silicates, carbonates, well-crystallised manganates, well-crystallised iron oxyhydroxides). $\delta-\mathrm{MnO}_{2}$ is barely visible on diffractograms even when it constitutes the main crystalline phase of a sample. Estimation of the proportion of $\delta-\mathrm{MnO}_{2}$ from other crystalline phases is made on the basis of a qualitative analysis of the diffractograms, i.e., ratio between $\delta-\mathrm{MnO}_{2}$ visible peaks $\left( \pm 37^{\circ}\right.$ and $\pm 66^{\circ} 2 \theta$; $2.45 \AA$ and $1.42 \AA$ ) and peak signals of other well-crystallised minerals.

Scanning electron microscopy (SEM) imaging was done with an FEI Quanta 200 SEM on C-coated polished thin sections. Backscatter images were acquired for textural charac- 
terisation of the Fe-Mn oxyhydroxides. Energy Dispersive Spectroscopy (EDS) analysis was performed with and OXFORD X-MAX ${ }^{\mathrm{N}}$ Silicon Drift Detector (detector size: $80 \mathrm{~mm}^{2}$ ).

\subsection{Geochemical Analyses}

$X$-ray fluorescence analyses were conducted with a wavelength dispersive $\mathrm{X}$-ray fluorescence spectrometer (WD-XRF; BRUKER AXS S8 TIGER) on fusion beads or compressed pellets (for major and trace elements, respectively). After data acquisition, measured net peak intensities corrected from inter-element interferences were converted into concentrations using calibration curves generated from the analysis of certified reference material powders (using BHVO-2 [60]), measured under identical analytical conditions.

Additional trace elements ( $\mathrm{Sr}, \mathrm{Y}, \mathrm{Zr}, \mathrm{Nb}$, Th, REE) were analysed for 17 hydrogenetic crusts from the Loyalty, Norfolk and D'Entrecasteaux ridges (Figure 2) by inductively coupled plasma mass spectrometry using an ELEMENT II magnetic field ICP-MS at Institut Universitaire Européen de la Mer (IUEM) in Brest. The dissolution procedure was as follows; $0.1 \mathrm{~g}$ of sample powder was digested in a Teflon bottle with $4 \mathrm{~mL}$ of $6 \mathrm{~mol} / \mathrm{L}$ hydrochloric acid for $24 \mathrm{~h}$ on a hot plate $\left(120^{\circ} \mathrm{C}\right)$ with a Tm spike [61,62]. If present, the residual phase composed of mostly silicates and refractory minerals was extracted by centrifuge and digested by a mixture of hydrofluoric and hydrochloric acid (3:1) for $48 \mathrm{~h}$ on hot plate $\left(120^{\circ} \mathrm{C}\right)$, evaporated and then remixed with the previously digested phase. Then, $0.5 \mu \mathrm{L}$ of the solution was evaporated on a hot plate and the residue was made up to $10 \mathrm{~mL}$ with a $2 \%$ nitric and $0.05 \%$ hydrofluoric acid solution for trace element analysis by ICP-MS. Samples were corrected using internal calibrations, BHVO-2 reference material, and a Tm spike correction [62]. Every concentration later in the text expressed as \% represents weight $\%$.

The Co-chronometer method considers that the supply of Co in the ocean is constant over time and that $\mathrm{Fe}$ and $\mathrm{Mn}$ oxides are the main scavengers of this element $[63,64]$. Considering these hypotheses, a proportional relationship can be established to estimate growth rates. Using crusts' thicknesses, it is possible to derive minimum crusts ages from growth rates. However, this method cannot account for post-depositional events like phosphatisation, dissolution, or erosional events that are known to affect Co concentration, preservation of the stratigraphic record, and could therefore alter calculated ages $[1,65]$. The minimal age of crusts was determined using the empirically derived cobalt chronometer method defined as: $\mathrm{GR}=0.68 /\left(\mathrm{Co}^{\mathrm{n}}\right)^{1.67}[66]$, where $\mathrm{GR}$ is the growth rate in $\mathrm{mm} / \mathrm{Ma}$, and $\mathrm{Co}^{\mathrm{n}}=\mathrm{Co} \times(50 / \mathrm{Fe}+\mathrm{Mn})$ with elements in wt.\%. The equation of [64] was not considered to compute the growth rate as several samples exhibit Co content lower than $0.24 \%$, which is the threshold needed to apply this method.

Several methods were used to examine statistically significant variations in major and minor elements concentrations for selected crusts samples. A Pearson correlation coefficient matrix was computed using chemical data to evaluate the strength of linear dependence between variables. To investigate possible chemical factor variations and biases in the data set, a matrix was produced using hydrogenetic macro-layers and bulk samples $(n=89)$. Bulk samples that have been subsampled were not considered to avoid duplicating data. All correlation coefficients in bold are significant at the $99 \%$ confidence level (CL). Factor analysis of the major and minor elements data was also run on the same data set $(n=89)$ to study element relationships and to determine groups of elements with the same behaviour. Using $X$-ray diffraction mineralogy and correlation coefficient matrices, each resultant factor of this analysis can be interpreted as a specific mineral or group of minerals in the Fe-Mn crusts and elements correlated with those factors to be part of the mineral group or mineral.

\section{Results}

\subsection{Sample Description}

Two types of samples can be distinguished from the macroscopic study: (1) Brown to black Fe-Mn encrustations which are referred here as Fe-Mn crusts, and (2) Grey to dark and rarely brownish grey Mn-rich $( \pm \mathrm{Ca}-\mathrm{Fe})$ samples. Fe-Mn crusts show a large diversity of surface and layered textures (Figure 3A-D). The surface can be smooth, granular and 
botryoidal, with botryoids ranging from millimeters to centimeters. Layers can be well separated from others with interstitial sediment and porous, columnar, dendritic, or very dense and well laminated. The thickness of Fe-Mn crusts vary from $2 \mathrm{~mm}$ to $115 \mathrm{~mm}$, with a mean thickness of $27 \mathrm{~mm}$ (from 61 hydrogenetic bulk samples). The thickest crusts can contain up to four distinct macroscopic layers, but no uniform sequence of texture has been found between these crusts. Mn-rich ( \pm Ca-Fe) samples (DW778B, DW778D, DW778D2, DW4998E, DW4998D, and DW2482, Figure 3E-H) present different morphologies and textures. These samples are denser and harder than Fe-Mn crusts. Some samples (Figure $3 \mathrm{~F}, \mathrm{H}$ ) display a strong imbrication of a metallic black zone and a pale white/reddish zone, showing colloform to dendritic-like growth textures in parts of the sample. Other samples (Figure 3E,G) present comparable macro-layers with metallic black and blue/grey units, as well as colors ranging from pale grey/blue and white/reddish to metallic black. Alternation of macro-layers is visible in Figure 3E, with an innermost imbrication of pale grey, blue and white layers, presenting in some areas a more or less porous and colloform texture, followed by a black metallic layer present on both sides of the sample. Whilst most previous analysis reports samples of a hydrogenetic nature, these morphological and visual characteristics match criterion proposed by [11] of a hydrothermal nature or influence.

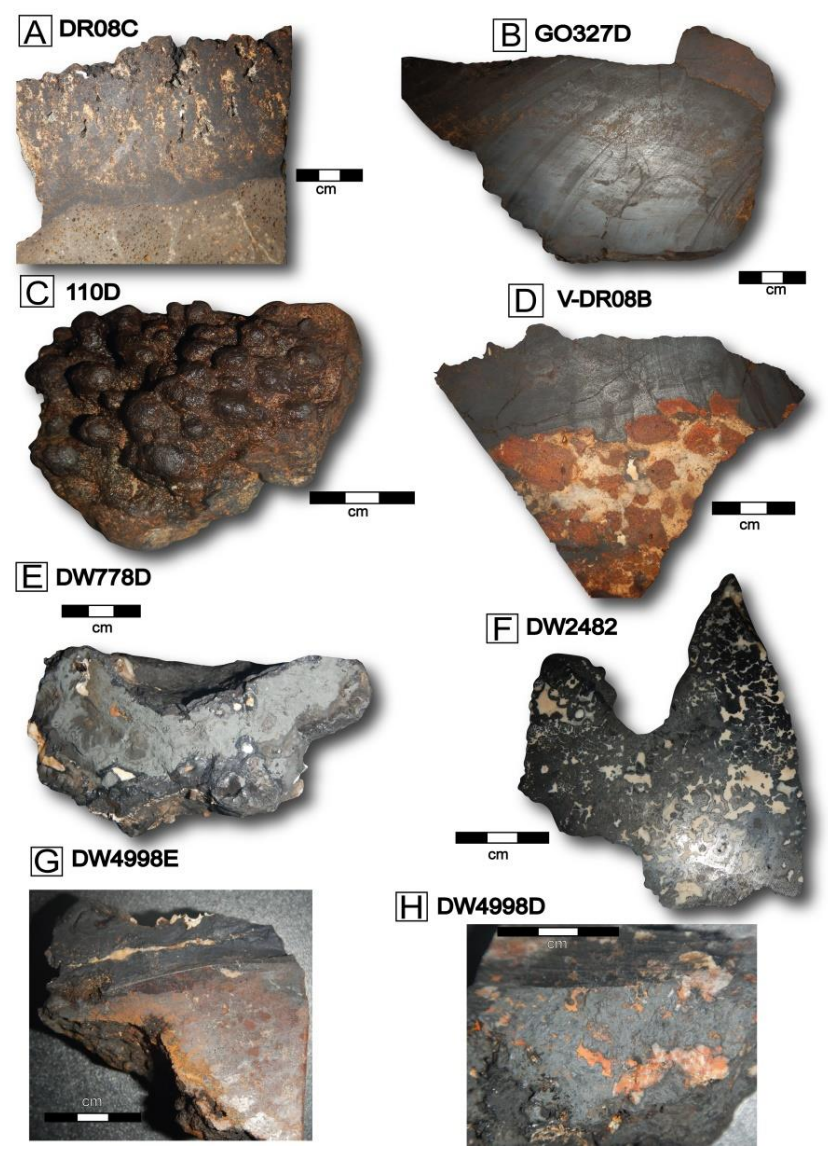

Figure 3. Fe-Mn deposits photographs with centimetre scale bars. (A) Cross-section of DR08C showing a columnar/porous texture with interstitial sediments filling pores, deposited on a vacuolar basalt; (B) Cross section of the thickest crust sample of the data set GO327D, four layers are identified and sub-sampled; (C) Current-polished centimetre-scale botryoidal surface of sample 110D; (D) V-DR08B showing massive/laminated textures without any sub-layers deposited on a hyaloclastite breccia; (E) Hydrothermal deposit from sample DW778D; (F) Imbrication of Mn-rich and Ca-rich zones in sample DW2482; (G) Sample DW4998E composed primarily of 10 Å manganates and calcite on a strongly altered hyaloclastite breccia impregnated with Fe-oxyhydroxides; $(\mathbf{H})$ Sample DW4998D showing a metallic grey Mn-rich zone and fluorapatite/Mg-calcite/calcite area. 


\subsection{XRD and SEM Mineralogy}

XRD mineralogical analyses are reported in Table 2. $\delta-\mathrm{MnO}_{2}$ is the most dominant phase detected in Fe-Mn crusts. Given no Fe mineral was identified on XRD, we conclude that most of the $\mathrm{Fe}$ is in the form of $\mathrm{X}$-ray amorphous Fe-oxyhydroxides [1,2] and/or Fe-rich $\delta-\mathrm{MnO}_{2}$. In most crusts, quartz, feldspar, calcite, and Mg-calcite represent the main detrital components. Other detrital phases include mica, clay minerals (DR19K, DR19K-1, DR21Biii, GO310 and DR08C), gypsum and amphibole (114D and GO310). Samples where the only $\mathrm{Mn}$ phase is $\delta-\mathrm{MnO}_{2}$ are characteristic of hydrogenetic ferromanganese crusts. They generally show complex internal structures including laminated layers of Fe-Mn oxides with varying porosities, cuspate texture (i.e., more porous and chaotic structure) or massive jointed columnar texture with only small amounts of detrital minerals (Figure 4A-C). Only one Fe-Mn crust sample (DN5080B) contains detectable amounts of fluorapatite.

Table 2. XRD and SEM mineralogy of ferromanganese deposits $(n=104)$ from New Caledonia.

\begin{tabular}{|c|c|c|c|}
\hline Sample & Major & Moderate & Minor \\
\hline 102D & - & - & - \\
\hline $105 \mathrm{D}$ & - & - & - \\
\hline 108D & - & - & - \\
\hline 109D & - & - & - \\
\hline 110D & $\delta$-MnO2, Quartz, Plagioclase & - & Calcite \\
\hline $113 \mathrm{D}$ & $\delta-\mathrm{MnO} 2$ & - & Quartz, Plagioclase \\
\hline $114 \mathrm{D}$ & $\delta-\mathrm{MnO} 2$ & Plagioclase, Calcite & Quartz, Gypsum \\
\hline $116 \mathrm{D}$ & $\delta-\mathrm{MnO} 2$ & Quartz, Plagioclase & - \\
\hline 117D & $\delta-\mathrm{MnO} 2$ & - & Quartz \\
\hline CP5069 & $\delta-\mathrm{MnO} 2$ & Fluorapatite, Calcite & $10 \AA$ manganates \\
\hline DN5064 & $\delta-\mathrm{MnO} 2$ & - & Calcite \\
\hline DN5079 & $\delta-\mathrm{MnO} 2$ & Quartz & Plagioclase \\
\hline DN5080B & $\delta-\mathrm{MnO} 2$ & - & Fluorapatite, Quartz \\
\hline DN5085A & $\delta-\mathrm{MnO} 2$, Quartz & - & Plagioclase \\
\hline DR01A & $\delta-\mathrm{MnO} 2$ & - & - \\
\hline DR04C & $\delta-\mathrm{MnO} 2$, Quartz & - & Plagioclase \\
\hline DR06B & $\delta-\mathrm{MnO} 2$ & Quartz & $\begin{array}{l}\text { Mg-Calcite, } \\
\text { Plagioclase }\end{array}$ \\
\hline DR07B & $\delta-\mathrm{MnO} 2$ & - & - \\
\hline DR08C & $\delta$-MnO2, Calcite & Clays/Micas, Quartz & Plagioclase \\
\hline DR10B & $\delta-\mathrm{MnO} 2$ & - & Quartz \\
\hline DR11Ai & $\delta$-MnO2, Quartz & Plagioclase & - \\
\hline DR11Ai-1 & Quartz, Plagioclase & 8-MnO2 & - \\
\hline DR11Ai-2 & $\delta-\mathrm{MnO} 2$, Quartz & Plagioclase & - \\
\hline DR11Ai-3 & $\delta-\mathrm{MnO} 2$, Quartz & Plagioclase & - \\
\hline DR11Ai-4 & $\delta-\mathrm{MnO} 2$, Quartz & Plagioclase & - \\
\hline DR13Bii & $\delta$-MnO2, Quartz & Calcite & - \\
\hline DR13Ci & $\delta-\mathrm{MnO} 2$ & Calcite & Quartz \\
\hline DR13D & $\delta-\mathrm{MnO} 2$ & Quartz & Calcite, Plagioclase \\
\hline DR14F & $\delta-\mathrm{MnO} 2$ & Quartz & - \\
\hline DR14F-1 & $\delta-\mathrm{MnO} 2$ & Quartz & Calcite, Plagioclase \\
\hline DR14F-2 & $\delta-\mathrm{MnO} 2$ & Quartz & - \\
\hline DR14H & $\delta-\mathrm{MnO} 2$, Quartz & Plagioclase & - \\
\hline DR15A & $\delta-\mathrm{MnO} 2$ & Quartz, Plagioclase & - \\
\hline DR18F & $\delta-\mathrm{MnO} 2$ & - & Plagioclase \\
\hline DR19K & $\delta$-MnO2, Clays/Micas & - & Quartz, Calcite \\
\hline DR19K-1 & $\delta$-MnO2, Clays/Micas & Calcite & Quartz, Plagioclase \\
\hline DR19K-2 & $\delta-\mathrm{MnO} 2$ & Quartz & - \\
\hline DR21Biii & $\delta$-MnO2, Clays/Micas & Quartz, Plagioclase & - \\
\hline DR21F & $\delta-\mathrm{MnO} 2$ & Quartz & Plagioclase \\
\hline DR21F-1 & $\delta-\mathrm{MnO} 2$ & Quartz & Plagioclase \\
\hline DR21F-2 & $\delta-\mathrm{MnO} 2$ & Quartz & Plagioclase \\
\hline
\end{tabular}


Table 2. Cont.

\begin{tabular}{|c|c|c|c|}
\hline Sample & Major & Moderate & Minor \\
\hline DR22A & $\delta-\mathrm{MnO} 2$ & Quartz & Plagioclase \\
\hline DR29F & $\delta-\mathrm{MnO} 2$ & Quartz & Quartz \\
\hline DR38C & $\delta-\mathrm{MnO} 2$ & - & Quartz, Calcite \\
\hline DR38C-1 & $\delta-\mathrm{MnO} 2$ & - & Quartz \\
\hline DR38C-2 & $\delta-\mathrm{MnO} 2$ & Calcite & Quartz \\
\hline DR41Ai & $\delta-\mathrm{MnO} 2$, Plagioclase & Quartz & - \\
\hline DR42B & $\delta-\mathrm{MnO} 2$ & - & - \\
\hline DR48-021 & $\delta-\mathrm{MnO} 2$, Quartz & - & Plagioclase \\
\hline DR53-008 & $\delta-\mathrm{MnO} 2$ & - & Quartz \\
\hline DR54-009 & $\delta-\mathrm{MnO} 2$ & - & Quartz, Plagioclase \\
\hline DW4998D & Pyrolusite & Mg-Calcite & Calcite, Fluorapatite \\
\hline DW4998E & Fe-oxyhydroxides, Calcite & $\begin{array}{c}\text { Fluorapatite, } 10 \AA \\
\text { manganates }\end{array}$ & \\
\hline DW5067B & $\delta-\mathrm{MnO} 2$ & Calcite & - \\
\hline DW5070A & $\delta-\mathrm{MnO} 2$ & - & Quartz, Calcite \\
\hline DW5073 & $\delta-\mathrm{MnO} 2$ & - & Calcite \\
\hline DW5086B & $\delta-\mathrm{MnO} 2$ & Quartz & Plagioclase \\
\hline DW5087 & $\delta-\mathrm{MnO} 2$ & Quartz & Plagioclase \\
\hline DW5089B & $\delta-\mathrm{MnO} 2$ & - & Quartz \\
\hline DW5090B & $\delta-\mathrm{MnO} 2$ & - & Quartz \\
\hline DW5091A & $\delta-\mathrm{MnO} 2$ & Quartz & Calcite \\
\hline DW772 & $\delta-\mathrm{MnO} 2$ & - & - \\
\hline DW774 & $\delta-\mathrm{MnO} 2$ & - & Calcite \\
\hline DW778B & Pyrolusite & Mg-Calcite & - \\
\hline DW778D & Pyrolusite & Mg-Calcite & - \\
\hline DW778D2 & Pyrolusite & Mg-Calcite & \\
\hline DW2482 & $10 \AA$ manganates & Mg-Calcite & Fluorapatite \\
\hline E-DR08B & $\delta$-MnO2, Quartz & Plagioclase & - \\
\hline E-DR08B-1 & $\delta$-MnO2, Quartz & - & Plagioclase \\
\hline E-DR08B-2 & $\delta$-MnO2, Quartz & - & - \\
\hline E-DR08B-3 & $\delta-\mathrm{MnO} 2$, Quartz & Plagioclase & - \\
\hline GO14D & $\delta-\mathrm{MnO} 2$ & - & - \\
\hline GO15D & $\delta-\mathrm{MnO} 2$ & Calcite & Quartz, Plagioclase \\
\hline GO16D & $\delta-\mathrm{MnO} 2$ & Quartz & Plagioclase, Calcite \\
\hline GO18D & $\delta-\mathrm{MnO} 2$ & - & Quartz, Plagioclase \\
\hline GO202 & $\delta$-MnO2, Quartz & - & Plagioclase \\
\hline GO209 & $\delta-\mathrm{MnO} 2$ & Quartz & Plagioclase \\
\hline GO20D & $\delta-\mathrm{MnO} 2$ & - & Quartz \\
\hline GO302D & $\delta$-MnO2, Plagioclase & Quartz & - \\
\hline GO302D-1 & $\delta-\mathrm{MnO} 2$, Plagioclase & Quartz & - \\
\hline GO302D-2 & $\delta-\mathrm{MnO} 2$, Plagioclase & Quartz & - \\
\hline GO310 & $\delta$-MnO2, Clays/Micas & Amphibole & $\begin{array}{c}\text { Quartz, Calcite, } \\
\text { Plagioclase }\end{array}$ \\
\hline GO314D10 & - & - & - \\
\hline GO316D31 & - & - & - \\
\hline GO317D10 & - & - & - \\
\hline GO320 & $\delta-\mathrm{MnO} 2$ & - & Plagioclase, Quartz \\
\hline GO321D2 & - & - & - \\
\hline GO322D4 & - & - & - \\
\hline GO323D2 & - & - & - \\
\hline GO325D2 & - & - & - \\
\hline GO327D & $\delta$-MnO2, Quartz & Plagioclase & - \\
\hline GO327D-1 & $\delta$-MnO2, Quartz & - & Plagioclase \\
\hline GO327D-2 & $\delta-\mathrm{MnO} 2$, Quartz & - & Plagioclase \\
\hline GO327D-3 & $\delta$-MnO2, Quartz & - & Plagioclase \\
\hline GO327D-4 & $\delta$-MnO2, Quartz & - & Plagioclase \\
\hline GO338D2 & - & - & - \\
\hline GO347D & - & - & - \\
\hline GO348D6 & $\delta-\mathrm{MnO} 2$ & - & Quartz \\
\hline
\end{tabular}


Table 2. Cont.

\begin{tabular}{cccc}
\hline Sample & Major & Moderate & Minor \\
\hline GO350D6 & $\delta-\mathrm{MnO} 2$ & Quartz, Plagioclase & - \\
GO350D6-1 & $\delta-\mathrm{MnO} 2$ & Plagioclase, Quartz & - \\
GO350D6-2 & $\delta$-MnO2 & Quartz, Plagioclase & - \\
GO350D6-3 & $\delta-\mathrm{MnO} 2$ & - & Quartz, Plagioclase \\
GO3D & $\delta-\mathrm{MnO} 2$ & Quartz & Plagioclase \\
V-DR08B & $\delta-\mathrm{MnO}$, Quartz & Plagioclase & Calcite \\
\hline
\end{tabular}
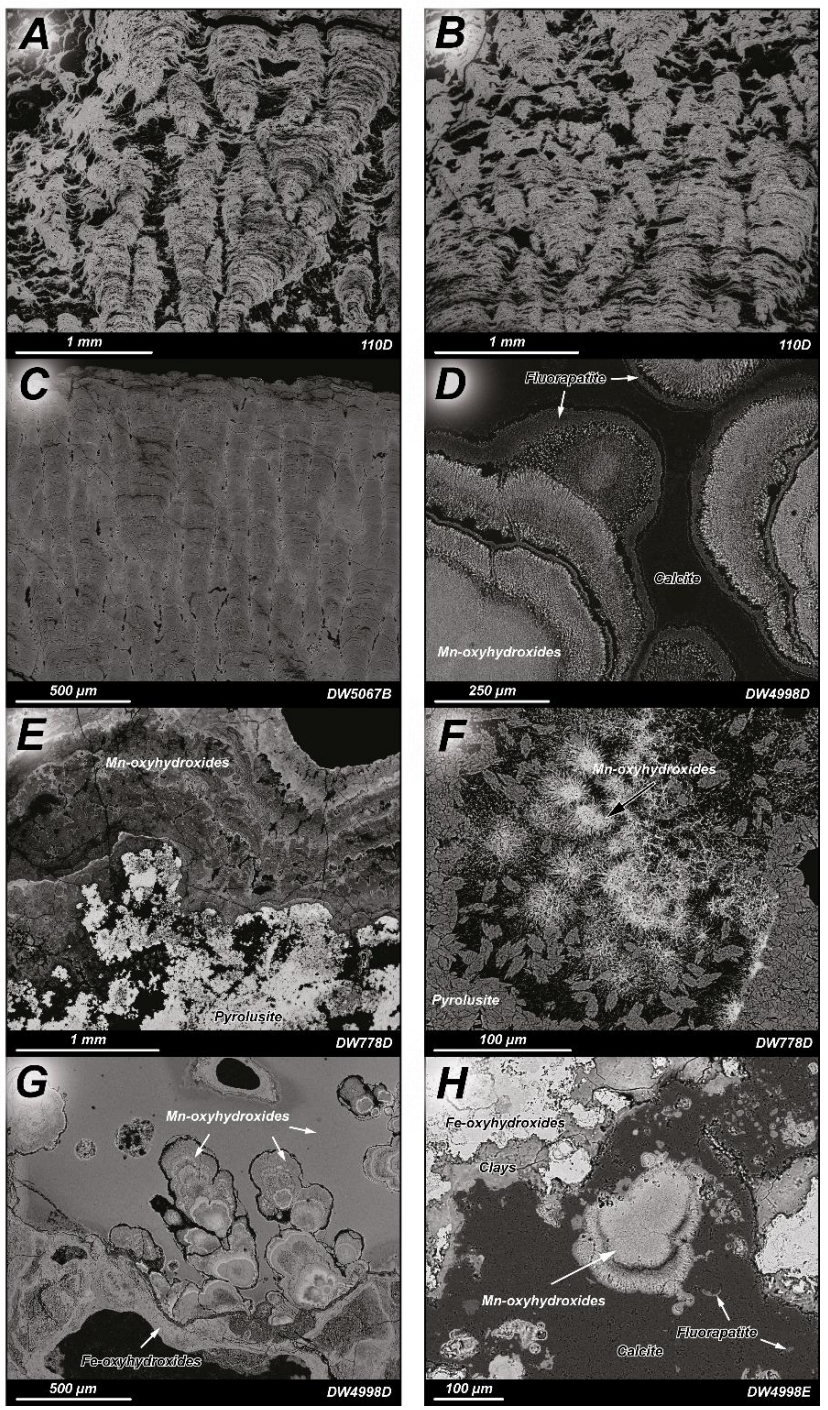

Figure 4. BSE images of selected Fe-Mn deposits samples. (A-D): Fe-Mn crusts; (E-H): Hydrothermal $\mathrm{Mn}+\mathrm{Ca} \pm$ Fe deposits; (A) Large columnar structure with quartz infill; (B) Laminar structure (bottom) evolving upwards to columnar structure; (C) Massive columnar texture formed by dense pillar structure with little amount of carbonate infill; (D) Well-crystallised needle-like Mnoxyhydroxides with overgrowth or crosscut by Ca-phosphate (fluorapatite); (E) Well-crystallised needle-like Mn-oxyhydroxides infilling cavity and surrounded by pyrolusite; (F) Pyrolusite and \pm calcite replacing areas composed of alternating layers of amorphous crystalline and microcrystalline Mn-oxyhydroxides; (G) Radially-oriented and spherulitic structure showing alternating layers of amorphous crystalline, microcrystalline and crystalline Mn-oxyhydroxides cemented by a massive microcrystalline Mn-oxyhydroxides; (H) Microcrystalline and crystalline Mn-oxyhydroxides observed between hydrothermally altered hyaloclastite clasts replaced by clays and Fe-oxyhydroxides; a subsequent carbonate and Ca-phosphate (fluorapatite) infilling event is observed. 
Mn-rich ( \pm Ca-Fe) samples (DW4998D, DW4998E, DW778B, DW778D, DW778D2 and DW2482) contain significant amounts of $10 \AA$ manganates and/or pyrolusite, which reflect a diagenetic and/or hydrothermal contribution [65]. These samples might contain a significant amount of $\delta-\mathrm{MnO}_{2}$, but its presence (based on $2.46 \AA$ and $1.42 \AA$ XRD reflections) is difficult to determine when $10 \AA$ manganates and/or pyrolusite are detected on diffractograms. All samples containing $10 \AA$ manganates also show moderate to minor amounts of Caphosphate (fluorapatite) (Figure 4D). Pyrolusite is abundant in four samples (DW4998D, DW778B, DW778D and DW778D2). Pyrolusite is a manganese oxide $\left(\mathrm{MnO}_{2}\right)$ encountered in hydrothermal deposits with a high oxidation state or forming following oxidation of primary todorokite (10 ̊ manganates) during diagenetic processes [67-69]. In DW778D, pyrolusite associated with calcite progressively replaces first-stage Mn minerals composed of an alternation of amorphous crystalline and microcrystalline Mn-oxyhydroxides (Figure 4E). In some places, acicular/fibrous Ba-rich Mn oxyhydroxides are observed in pore spaces between pyrolusite minerals (Figure 4F). Spherulitic structure characterised by alternating amorphous, microcrystalline and crystalline Mn-oxyhydroxides were also observed in the hydrothermal/diagenetic samples (Figure 4G). Sample DW4998E presents characteristics of a strongly hydrothermally-altered hyaloclastite (Figure 3G), mainly composed of calcite and amorphous Fe-oxyhydroxides, with minor clays and Mn-oxyhydroxides (Figure $4 \mathrm{H}$ ).

\subsection{Geochemistry}

\subsubsection{Fe-Mn Samples Classification}

A ternary plot of $\mathrm{Fe}, \mathrm{Mn}$ and $(\mathrm{Co}+\mathrm{Cu}+\mathrm{Ni}) \times 10$ [70] (Figure 5A) shows that the majority of our samples (including DW4998E sample) fall within the hydrogenetic field [71]. This is in good agreement with macroscopic and mineralogical results, which point out that most of the samples $(n=98 / 104)$ can be referred to as hydrogenetic Fe-Mn crusts. However, one sample (i.e., DW4998E) with hydrothermal macroscopic and mineralogical characteristics is plot in the hydrogenetic field due to high $\mathrm{Co}, \mathrm{Ni}$ and $\mathrm{Cu}$ concentrations. The last five samples (DW2482, DW788B, DW778D, DW778D2 and DW4998D) fall within the overlap of the diagenetic and the hydrothermal part of the diagram, consistent with the observed morphologies and mineralogy. The second diagram [72] (Figure 5B) plots $(\mathrm{Fe}+\mathrm{Mn}) / 4,100 \times(\mathrm{Zr}+\mathrm{Y}+\mathrm{Ce}), 15 \times(\mathrm{Cu}+\mathrm{Ni})$ and shows a major clustering of samples in the lower part of the hydrogenetic area as well. Two samples (DN5085A and GO16D) plot slightly below the hydrogenetic field, due to high contents of $\mathrm{Cu}$ and $\mathrm{Ni}$ and relatively low Zr, Ce and Y concentrations. Four samples (DW778D, DW778D2, DW778B and DW4998D) are located within the hydrothermal fall-out crusts and impregnations, strengthening our interpretation of a hydrothermal origin. DW4998E and DW2482 are distributed between the diagenetic and the hydrothermal field.

A

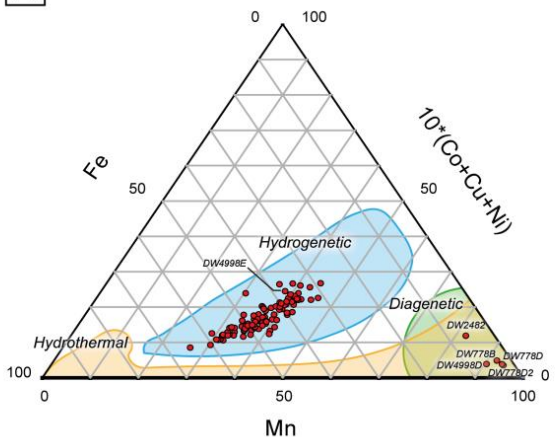

B

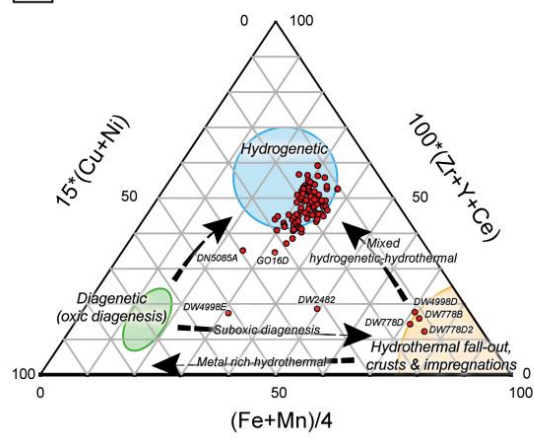

Figure 5. Ternary classification schemes of Fe-Mn samples from New Caledonia's EEZ $(n=104)$ after (A) [70] and (B) [72].

The classification of [73] requires full REE determination which was only produced on 17 of the 104 samples of this set. Nonetheless, the 17 analysed samples plot in the 
hydrogenetic field are in good agreement with other classification for this subset (Figure 6).

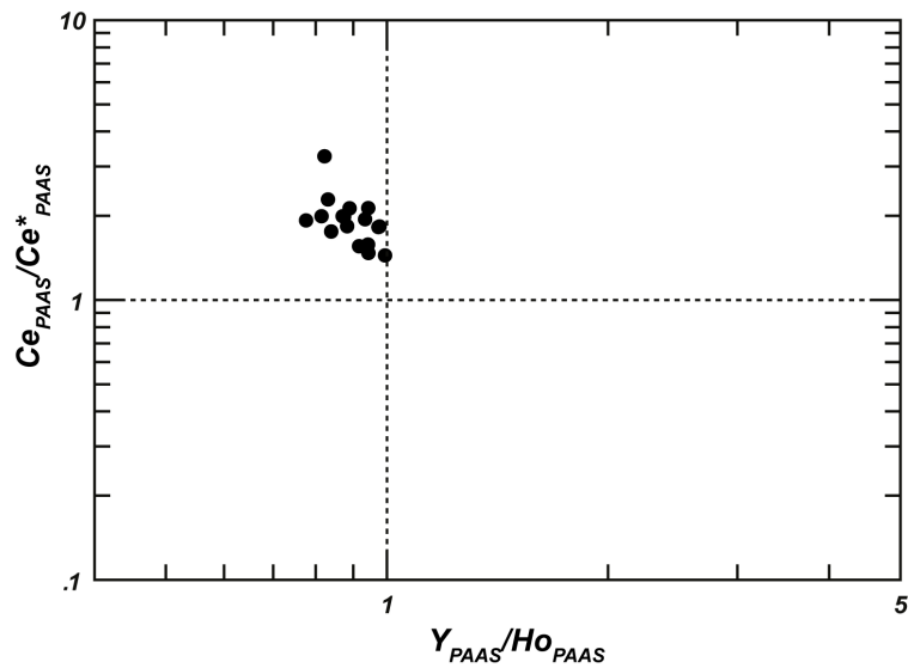

Figure 6. Genetic discrimination plot of the selected hydrogenetic crusts after [73].

\subsubsection{Hydrogenetic Fe-Mn Crusts}

For the combined hydrogenetic data set $(n=98)$, chemical composition of bulk and macro-layers is presented as mean $\pm 2 \sigma \%$ (Table 3; Supplementary Material Table S1). The mean $\mathrm{Fe} / \mathrm{Mn}$ ratio for the combined data set is $1.26 \pm 0.66$ and the mean $\mathrm{Si} / \mathrm{Al}$ ratio is $3.76 \pm 2.37$. The highest values of $\mathrm{Si} / \mathrm{Al}$ ratio are found in layers of the thickest crusts (e.g., GO327D-4, GO327D-3 and DR11Ai-3). The mean combined $\mathrm{Cu}+\mathrm{Ni}+\mathrm{Co}(\%)$ concentration is $0.81 \pm 0.56 \%$. This wide variation in metals with the greatest economic interest is mainly controlled by cobalt concentrations ranging from $0.16 \%$ to $1.02 \%$. However, few Fe-Mn crusts samples (e.g., DN5085A, GO16D) are dominated by nickel enrichment with concentrations up to $0.61 \%$.

Table 3. Statistics for the geochemical data sets normalised to $0 \% \mathrm{H}_{2} \mathrm{O}^{-}$.

\begin{tabular}{|c|c|c|c|c|c|c|c|c|c|}
\hline \multirow[b]{2}{*}{ Element } & \multicolumn{3}{|c|}{$\begin{array}{l}\text { Hydrogenetic Bulk and } \\
\text { Macro-Layers Crusts }\end{array}$} & \multicolumn{6}{|c|}{ Hydrothermal/Diagenetic Deposits } \\
\hline & $N$ & Mean & $\pm 2 \sigma$ & DW778B & DW778D & DW778D2 & DW4998D & DW4998E & DW2482 \\
\hline$\left(\mathrm{H}_{2} \mathrm{O}^{-\mathrm{a}}\right)(\%)$ & 85 & 10.26 & 11.93 & 0.42 & 0.36 & 0.82 & 0.6 & 2.61 & 1.59 \\
\hline $\mathrm{LOI}^{\mathrm{b}}$ & 85 & 17.98 & 4.6 & 17.34 & 17.76 & 17.36 & 21.46 & 21.35 & 18.91 \\
\hline $\mathrm{Mn}$ & 98 & 17.37 & 7.18 & 50.38 & 48.37 & 48.82 & 28.96 & 14.03 & 38.44 \\
\hline $\mathrm{Fe}$ & 98 & 20.79 & 3.57 & 1.27 & 1.59 & 1.28 & 1.82 & 13.67 & 2.8 \\
\hline $\mathrm{Si}$ & 98 & 6.15 & 5.98 & 0.49 & 0.53 & 0.51 & 0.35 & 1.07 & 0.29 \\
\hline $\mathrm{Al}$ & 98 & 1.63 & 1.5 & 0.25 & 0.27 & 0.23 & 0.28 & 1.99 & 0.57 \\
\hline $\mathrm{Mg}$ & 98 & 1.28 & 0.69 & 0.99 & 0.92 & 0.8 & 1.25 & 3.58 & 2.31 \\
\hline $\mathrm{Na}$ & 98 & 1.56 & 0.42 & 0.42 & 0.32 & 0.21 & 0.3 & 0.42 & 0.84 \\
\hline $\mathrm{Ca}$ & 98 & 2.61 & 1.69 & 6.21 & 7.54 & 8.14 & 17.79 & 13.52 & 8.67 \\
\hline K & 98 & 0.42 & 0.29 & 0.2 & 0.13 & 0.11 & 0.13 & 0.2 & 0.37 \\
\hline $\mathrm{Ti}$ & 98 & 0.9 & 0.36 & 0.05 & 0.08 & 0.06 & 0.05 & 0.17 & 0.1 \\
\hline $\mathrm{P}$ & 98 & 0.57 & 0.31 & 0.53 & 0.41 & 0.37 & 1.88 & 1.97 & 1 \\
\hline As (ppm) & 98 & 275 & 136 & 71 & 72 & 59 & 63 & 260 & 89 \\
\hline $\mathrm{Ba}$ & 98 & 1500 & 560 & 8460 & 4946 & 3339 & 4151 & 869 & 11,719 \\
\hline $\mathrm{Ce}$ & 98 & 711 & 384 & 148 & 112 & 81 & 86 & 221 & 275 \\
\hline $\mathrm{Co}$ & 98 & 4188 & 3762 & 514 & 898 & 655 & 405 & 1409 & 1148 \\
\hline $\mathrm{Cr}$ & 85 & 45 & 78 & 10 & 10 & 10 & 10 & 35 & 12 \\
\hline $\mathrm{Cu}$ & 98 & 775 & 611 & 283 & 242 & 187 & 108 & 655 & 295 \\
\hline $\mathrm{La}$ & 98 & 239 & 88 & 88 & 105 & 96 & 74 & 80 & 88 \\
\hline Mo & 98 & 430 & 268 & 168 & 141 & 128 & 82 & 410 & 228 \\
\hline $\mathrm{Nb}$ & 98 & 60 & 26 & 5 & 10 & 7 & 7 & 18 & 15 \\
\hline
\end{tabular}


Table 3. Cont.

\begin{tabular}{|c|c|c|c|c|c|c|c|c|c|}
\hline \multirow[b]{2}{*}{ Element } & \multicolumn{3}{|c|}{$\begin{array}{l}\text { Hydrogenetic Bulk and } \\
\text { Macro-Layers Crusts }\end{array}$} & \multicolumn{6}{|c|}{ Hydrothermal/Diagenetic Deposits } \\
\hline & $N$ & Mean & $\pm 2 \sigma$ & DW778B & DW778D & DW778D2 & DW4998D & DW4998E & DW2482 \\
\hline $\mathrm{Nd}$ & 98 & 150 & 66 & 30 & 30 & 30 & 30 & 30 & 30 \\
\hline $\mathrm{Ni}$ & 98 & 3100 & 2185 & 1095 & 1432 & 1178 & 736 & 6936 & 4138 \\
\hline $\mathrm{Pb}$ & 98 & 1544 & 1176 & 219 & 359 & 257 & 171 & 322 & 349 \\
\hline $\mathrm{Pt}^{\mathrm{c}}$ & 46 & 0.66 & 0.8 & $<0.5$ & $<0.5$ & $<0.5$ & $<0.5$ & $<0.5$ & $<0.5$ \\
\hline $\mathrm{Rb}$ & 98 & $<5$ & $<5$ & $<5$ & $<5$ & $<5$ & $<5$ & 7 & $<5$ \\
\hline $\mathrm{Sr}$ & 98 & 1482 & 550 & 1858 & 1440 & 1261 & 1119 & 719 & 2656 \\
\hline $\mathrm{Tl}$ & 98 & 100 & 112 & 77 & 75 & 61 & 43 & 78 & 141 \\
\hline $\mathrm{V}$ & 98 & 751 & 336 & 271 & 263 & 214 & 289 & 796 & 525 \\
\hline $\mathrm{Y}$ & 98 & 165 & 66 & 62 & 65 & 61 & 68 & 74 & 41 \\
\hline $\mathrm{Zn}$ & 98 & 665 & 235 & 182 & 201 & 111 & 161 & 459 & 589 \\
\hline $\mathrm{Zr}$ & 98 & 535 & 170 & 73 & 73 & 61 & 39 & 91 & 73 \\
\hline $\mathrm{Co}+\mathrm{Cu}+\mathrm{Ni}(\%)$ & 98 & 0.81 & 0.56 & 0.19 & 0.26 & 0.2 & 0.12 & 0.9 & 0.56 \\
\hline $\mathrm{Si} / \mathrm{Al}$ & 98 & 3.76 & 2.37 & 1.96 & 1.96 & 2.22 & 1.25 & 0.54 & 0.51 \\
\hline $\mathrm{Fe} / \mathrm{Mn}$ & 98 & 1.26 & 0.66 & 0.03 & 0.03 & 0.03 & 0.06 & 0.97 & 0.07 \\
\hline
\end{tabular}

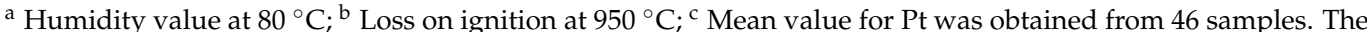
rest of the samples exhibit values below the detection limit of $0.5 \mathrm{ppm}$.

Rare earth elements (REE) concentrations of the 17 selected hydrogenetic crusts are compiled in Table 4 and PAAS-normalised [74] trends presented in Figure 7. REE data are consistent with typical hydrogenetic crusts [73]. The PAAS-normalised patterns are characterised by a two- to ten-fold enrichment in REE compared to average PAAS and present a positive Ce anomaly, and HREE-PAAS and/or MREE-PAAS enrichment (Figure 7. Total REE ( $\sum$ REE in Table 4) varies from $919 \mathrm{ppm}$ to $1705 \mathrm{ppm}$, with a mean value of $1307 \pm 426$ ppm. Percentage of heavy REE (HREE; Eu-Lu + Y in Table 4) varies between $14 \%$ and $27 \%$, with a mean value of $22 \pm 7 \%$.

Table 4. Rare earth elements (REE) compositions of the 17 samples analysed with ICP-MS.

\begin{tabular}{|c|c|c|c|c|c|c|c|c|c|c|c|c|c|c|c|c|c|c|}
\hline & DR102 & DR105 & DR108 & DR117 & GO14D & GO202 & GO209 & GO314D10 & GO316 & GO317D10 & GO321D1 & GO322 & GO323 & GO325 & GO338D2 & GO347 & Mean & $2 \sigma$ \\
\hline $\begin{array}{l}\text { Water } \\
\text { depth } \\
(\mathrm{m})\end{array}$ & 2525 & 2498 & 2080 & 1800 & 1450 & 2425 & 1310 & 3120 & 3200 & 3200 & 4190 & 3680 & 4180 & 4000 & 1600 & 2070 & 2751 & 1945 \\
\hline $\mathrm{La}$ & 169 & 187 & 192 & 216 & 289 & 205 & 210 & 138 & 148 & 151 & 135 & 199 & 166 & 177 & 202 & 181 & 186 & 75 \\
\hline $\mathrm{Ce}$ & 557 & 612 & 690 & 545 & 862 & 741 & 523 & 392 & 411 & 522 & 535 & 763 & 972 & 809 & 715 & 638 & 643 & 323 \\
\hline $\operatorname{Pr}$ & 26 & 32 & 34 & 34 & 45 & 37 & 34 & 24 & 26 & 32 & 25 & 40 & 29 & 38 & 30 & 26 & 32 & 12 \\
\hline $\mathrm{Nd}$ & 117 & 133 & 142 & 142 & 173 & 149 & 141 & 110 & 114 & 135 & 111 & 161 & 125 & 152 & 136 & 120 & 136 & 36 \\
\hline $\mathrm{Sm}$ & 24 & 27 & 29 & 28 & 35 & 31 & 28 & 23 & 24 & 30 & 24 & 35 & 26 & 34 & 27 & 23 & 28 & 8 \\
\hline $\mathrm{Eu}$ & 6 & 7 & 8 & 7 & 9 & 8 & 7 & 6 & 6 & 8 & 6 & 9 & 6 & 8 & 7 & 6 & 7 & 2 \\
\hline $\mathrm{Gd}$ & 29 & 31 & 35 & 35 & 38 & 35 & 34 & 29 & 29 & 35 & 28 & 37 & 28 & 36 & 33 & 29 & 33 & 7 \\
\hline $\mathrm{Tb}$ & 4 & 5 & 5 & 5 & 6 & 5 & 5 & 4 & 4 & 5 & 4 & 6 & 4 & 6 & 5 & 4 & 5 & 1 \\
\hline Dy & 27 & 28 & 33 & 34 & 35 & 33 & 33 & 26 & 27 & 32 & 27 & 33 & 25 & 33 & 32 & 29 & 31 & 7 \\
\hline Y & 149 & 140 & 164 & 215 & 162 & 163 & 206 & 125 & 142 & 153 & 135 & 153 & 114 & 138 & 186 & 191 & 156 & 57 \\
\hline Ho & 6 & 6 & 7 & 8 & 7 & 7 & 8 & 6 & 6 & 7 & 6 & 7 & 5 & 7 & 7 & 7 & 7 & 1 \\
\hline Er & 17 & 17 & 20 & 22 & 20 & 21 & 23 & 16 & 17 & 19 & 17 & 19 & 14 & 19 & 21 & 20 & 19 & 5 \\
\hline $\mathrm{Yb}$ & 16 & 16 & 19 & 21 & 18 & 19 & 21 & 15 & 16 & 17 & 16 & 17 & 13 & 18 & 19 & 18 & 17 & 4 \\
\hline $\mathrm{Lu}$ & 3 & 2 & 3 & 3 & 3 & 3 & 3 & 2 & 2 & 3 & 3 & 3 & 2 & 3 & 3 & 3 & 3 & 1 \\
\hline $\begin{array}{l}\sum \text { REE } \\
\% \text { HRE }\end{array}$ & 1155 & 1248 & 1385 & 1319 & 1705 & 1461 & 1281 & 919 & 975 & 1154 & 1077 & 1485 & 1535 & 1482 & 1426 & 1299 & 1307 & 426 \\
\hline $\begin{array}{c}\mathrm{Eu}- \\
\mathrm{Lu}+ \\
\mathrm{Y})\end{array}$ & 23 & 20 & 21 & 27 & 18 & 20 & 27 & 25 & 26 & 25 & 23 & 19 & 14 & 18 & 22 & 24 & 22 & 7 \\
\hline
\end{tabular}

\subsubsection{Non-Hydrogenetic Mn-Rich ( $\pm \mathrm{Ca}-\mathrm{Fe})$ Samples Deposits}

The six samples characterised by non-hydrogenetic morphologies and mineralogy (DW778B, DW778D, DW778D2, DW4998D, DW4998E and DW2482) fall in either the hydrothermal or diagenetic field of common classification schemes [72,73]. These samples have very low Fe/Mn ratios (<0.07), except for sample DW4998E (0.97) where the analysis incorporates both Mn-dominated mineralization and Fe-Ca-rich, hydrothermally-altered hyaloclastite. They have low content of elements characteristic of the aluminosilicate phase $(\mathrm{Si}, \mathrm{Al}, \mathrm{K}$ and $\mathrm{Na}$ ), but higher $\mathrm{Ca}$ concentrations compared to samples of hydrogenetic origin. Phosphorus is high and can reach a max of up to $2 \%$ related to the presence of fluorapatite. Cobalt is relatively low $(<0.15 \%)$ whereas $\mathrm{Ni}$, Ba and $\mathrm{Sr}$ reach concentrations 
up to $0.69 \%, 1.17 \%$ and $0.26 \%$, respectively. Other trace elements such as As, Ce, Cr, Mo, $\mathrm{Pb}, \mathrm{Nb}$, and $\mathrm{Zr}$ are depleted compared to usual hydrogenetic content.

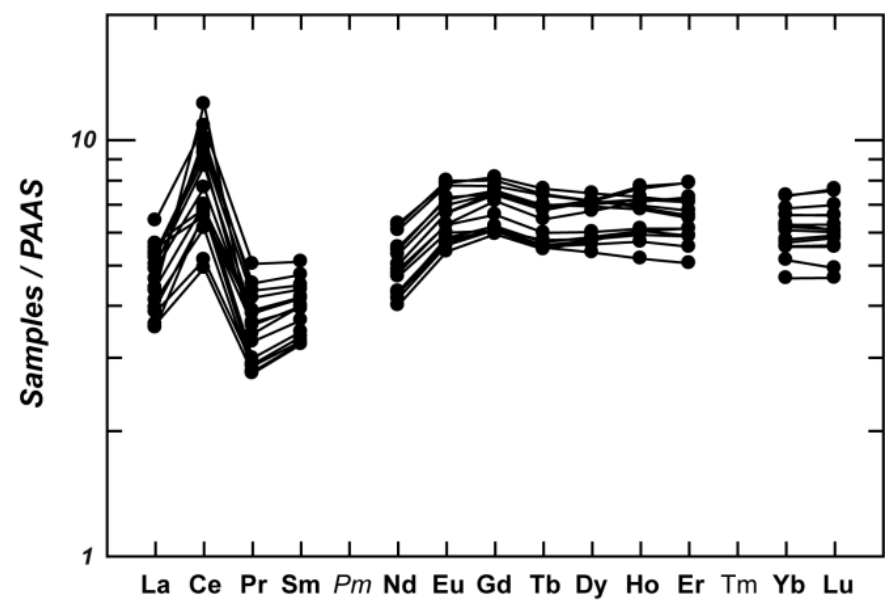

Figure 7. PAAS-normalised REE plots for selected hydrogenetic crusts.

\subsection{Growth Rates and Ages}

Estimated growth rates have been calculated using an empirical Co chronometer [66]. Growth rates vary from 0.45 to $102 \mathrm{~mm} / \mathrm{Ma}$ (Figure 8 ) and show no geographic correlations. Bulk hydrogenetic crusts $(n=74)$ have a mean growth rate of $2.2 \pm 2.5 \mathrm{~mm} / \mathrm{Ma}$. Growth rates for macro-layers sub-samples $(n=24)$ are on average higher, at $3.1 \pm 2.9 \mathrm{~mm} / \mathrm{Ma}$. Considering stratigraphic variations (Figure 8B), most samples (DR14F, DR21F, DR38C, GO302D) present an increasing growth rate towards the most recent period, whereas only one crust exhibits a decreasing growth rate (DR19K) towards its top two layers. These trends highlight why bulk samples, which could not be divided in macro-layers, have a lower average growth rate as they might only represent the most recent growth period. Hydrothermal/diagenetic deposits are characterised by higher growth rates than typical hydrogenetic crusts [75]. Our data set reveals values of 18.3, 38, 64, 64.7, and $102 \mathrm{~mm} / \mathrm{Ma}$, for samples DW2482, DW778D, DW778D2, DW4998D, and DW778B, respectively consistent with a hydrothermally or diagenetically influenced growth. Considering an apparent mean thickness of crust samples, it is possible to extrapolate a period of oxide accumulation, which represents the time it would have taken the crusts to form assuming no hiatuses, and could be assimilated with great care as a minimal age of initiation of growth. Assuming the surface of each sample represents present-day, the minimal age of initiation of growth ranges from 0.79 to $34.3 \mathrm{Ma}$. It was not possible to obtain ages for samples showing no signs of stratigraphic polarity without substrate.

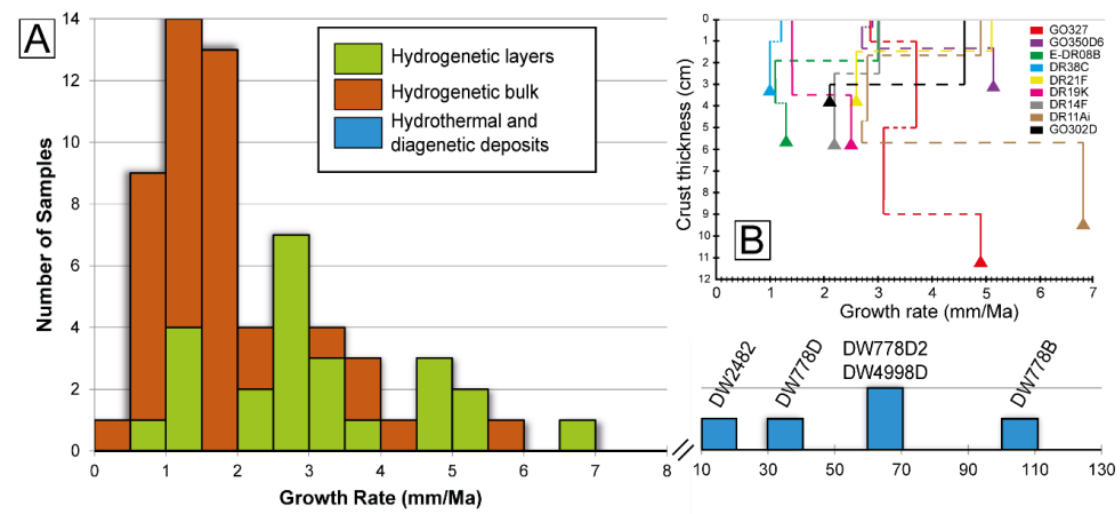

Figure 8. (A) Histogram of growth rates of New Caledonia's EEZ crusts samples using [66] equation; (B) Graph of the growth rate variation versus crust thickness of the samples with one or more sub-samples $(n=9)$. 


\subsection{Element Correlations}

A Pearson correlation coefficient matrix was calculated for the hydrogenetic macrolayers and bulk crusts $(n=89)$. Bulk samples that have been subsampled were not considered in the data set. In addition to 27 elements, the analysis contains growth rates and the $\mathrm{Fe} / \mathrm{Mn}$ ratios (Table 5). Based on statistically significant (CL > 99\%) correlations and identified mineralogical phases by $\mathrm{XRD}$, the statistical analysis reflects the major distribution of elements between four phases. A Mn oxide phase $\left(\delta-\mathrm{MnO}_{2}\right)$ contains $\mathrm{Mn}, \mathrm{Mo}, \mathrm{Sr}$, $\mathrm{Tl}, \mathrm{Pb}, \mathrm{Co}, \mathrm{La}, \mathrm{Ni}, \mathrm{V}, \mathrm{As}, \mathrm{Y}, \mathrm{Nd}, \mathrm{Nb}, \mathrm{Zn}$, and an Fe-oxyhydroxide phase with Fe and $\mathrm{Zr}$, whilst a biogenic phase accounts for $\mathrm{Ba}, \mathrm{Zn}$ and $\mathrm{Ce}$. Presence of calcite and fluorapatite identified in SEM images and XRD is consistent with the correlation of $\mathrm{Ca}, \mathrm{P}$ and $\mathrm{Pb}$. Aluminosilicate elements $\mathrm{Si}, \mathrm{Al}, \mathrm{Na}, \mathrm{K}, \mathrm{Cu}$ and $\mathrm{Zr}$ are negatively correlated with the $\delta-\mathrm{MnO}_{2}$ and Fe-oxyhydroxide phases, which is a common observation in other areas of the Pacific Ocean $[1,67]$. The distinction between a fluorapatite phase and a residual biogenic phase is not obvious. Only samples CP5069 and DN5080B contain fluorapatite, but no correlation has been found between $\mathrm{Ca}$ and principal biogenic elements ( $\mathrm{Ba}, \mathrm{Ce}$ and $\mathrm{Zn}$ ). The weak correlation between $\mathrm{Ni}, \mathrm{P}$ and Ca could be explained by the presence of $10 \AA$ manganates associated with fluorapatite in CP5069.

Table 5. Pearson correlation coefficients matrix for the hydrogenetic macro-layers and bulk crusts $(n=89)^{\mathrm{a}}$.

\begin{tabular}{|c|c|c|c|c|c|c|c|c|c|c|c|c|c|c|c|c|}
\hline & Mn & $\mathrm{Fe}$ & $\mathrm{Si}$ & Al & $\mathrm{Mg}$ & $\mathrm{Na}$ & $\mathrm{Ca}$ & K & $\mathrm{Ti}$ & $\mathbf{P}$ & As & Ва & $\mathrm{Ce}$ & Co & $\mathrm{Cu}$ & La \\
\hline Mn & 1 & -0.364 & -0.916 & -0.831 & 0.09 & -0.507 & 0.335 & -0.643 & 0.258 & 0.458 & 0.61 & 0.355 & 0.344 & 0.832 & -0.177 & 0.702 \\
\hline $\mathrm{Fe}$ & -0.364 & 1 & 0.233 & -0.013 & -0.552 & 0.007 & -0.519 & -0.079 & -0.135 & -0.246 & 0.048 & 0.015 & 0.121 & -0.37 & -0.271 & 0.057 \\
\hline Si & -0.916 & 0.233 & 1 & 0.801 & -0.127 & 0.485 & -0.494 & 0.675 & -0.21 & -0.54 & -0.699 & -0.268 & -0.269 & -0.797 & 0.264 & -0.661 \\
\hline Al & -0.831 & -0.013 & 0.801 & 1 & 0.127 & 0.578 & -0.174 & 0.833 & -0.1 & -0.441 & -0.713 & -0.433 & -0.487 & -0.68 & 0.345 & -0.778 \\
\hline $\mathrm{Mg}$ & 0.09 & -0.552 & -0.127 & 0.127 & 1 & -0.077 & 0.42 & 0.061 & -0.148 & 0.109 & 0.083 & -0.149 & -0.24 & 0.197 & 0.075 & -0.267 \\
\hline $\mathrm{Na}$ & -0.507 & 0.007 & 0.485 & 0.578 & -0.077 & 1 & -0.228 & 0.523 & 0.013 & -0.35 & -0.636 & -0.387 & -0.409 & -0.566 & 0.338 & -0.379 \\
\hline $\mathrm{Ca}$ & 0.335 & -0.519 & -0.494 & -0.174 & 0.42 & -0.228 & 1 & -0.291 & -0.075 & 0.691 & 0.469 & -0.03 & -0.109 & 0.377 & -0.221 & 0.055 \\
\hline $\mathbf{K}$ & -0.643 & -0.079 & 0.675 & 0.833 & 0.061 & 0.523 & -0.291 & 1 & 0.07 & -0.434 & -0.768 & -0.186 & -0.307 & -0.583 & 0.554 & -0.62 \\
\hline $\mathrm{Ti}$ & 0.258 & -0.135 & -0.21 & -0.1 & -0.148 & 0.013 & -0.075 & 0.07 & 1 & -0.211 & -0.307 & 0.324 & 0.373 & 0.347 & 0.255 & 0.44 \\
\hline $\mathbf{P}$ & 0.458 & -0.246 & -0.54 & -0.441 & 0.109 & -0.35 & 0.691 & -0.434 & -0.211 & 1 & 0.63 & 0.269 & 0.1 & 0.342 & -0.243 & 0.175 \\
\hline As & 0.61 & 0.048 & -0.699 & -0.713 & 0.083 & -0.636 & 0.469 & -0.768 & -0.307 & 0.63 & 1 & 0.189 & 0.25 & 0.602 & -0.633 & 0.457 \\
\hline Ba & 0.355 & 0.015 & -0.268 & -0.433 & -0.149 & -0.387 & -0.03 & -0.186 & 0.324 & 0.269 & 0.189 & 1 & 0.754 & 0.163 & 0.113 & 0.484 \\
\hline $\mathrm{Ce}$ & 0.344 & 0.121 & -0.269 & -0.487 & -0.24 & -0.409 & -0.109 & -0.307 & 0.373 & 0.1 & 0.25 & 0.754 & 1 & 0.341 & -0.012 & 0.619 \\
\hline Co & 0.832 & -0.37 & -0.797 & -0.68 & 0.197 & -0.566 & 0.377 & -0.583 & 0.347 & 0.342 & 0.602 & 0.163 & 0.341 & 1 & -0.229 & 0.582 \\
\hline $\mathrm{Cu}$ & -0.177 & -0.271 & 0.264 & 0.345 & 0.075 & 0.338 & -0.221 & 0.554 & 0.255 & -0.243 & -0.633 & 0.113 & -0.012 & -0.229 & 1 & -0.332 \\
\hline La & 0.702 & 0.057 & -0.661 & -0.778 & -0.267 & -0.379 & 0.055 & -0.62 & 0.44 & 0.175 & 0.457 & 0.484 & 0.619 & 0.582 & -0.332 & 1 \\
\hline Mo & 0.829 & -0.11 & -0.732 & -0.855 & -0.053 & -0.552 & 0.154 & -0.701 & 0.02 & 0.364 & 0.688 & 0.509 & 0.551 & 0.619 & -0.366 & 0.774 \\
\hline $\mathrm{Nb}$ & 0.48 & -0.165 & -0.485 & -0.453 & -0.011 & -0.37 & 0.166 & -0.324 & 0.697 & 0.108 & 0.187 & 0.329 & 0.398 & 0.68 & 0.042 & 0.508 \\
\hline $\mathrm{Nd}$ & 0.403 & 0.159 & -0.32 & -0.526 & -0.236 & -0.26 & -0.109 & -0.447 & 0.28 & 0.023 & 0.28 & 0.401 & 0.611 & 0.293 & -0.263 & 0.837 \\
\hline $\mathrm{Ni}$ & 0.805 & -0.64 & -0.716 & -0.549 & 0.486 & -0.433 & 0.396 & -0.399 & 0.091 & 0.395 & 0.462 & 0.206 & 0.173 & 0.754 & 0.073 & 0.302 \\
\hline $\mathbf{P b}$ & 0.82 & -0.255 & -0.804 & -0.759 & 0.177 & -0.624 & 0.366 & -0.68 & 0.132 & 0.401 & 0.736 & 0.322 & 0.307 & 0.815 & -0.359 & 0.596 \\
\hline $\mathrm{Sr}$ & 0.891 & -0.102 & -0.894 & -0.872 & -0.08 & -0.5 & 0.314 & -0.754 & 0.186 & 0.435 & 0.736 & 0.404 & 0.393 & 0.75 & -0.42 & 0.793 \\
\hline $\mathrm{Tl}$ & 0.853 & -0.529 & -0.788 & -0.625 & 0.238 & -0.531 & 0.44 & -0.457 & 0.332 & 0.445 & 0.506 & 0.417 & 0.403 & 0.819 & -0.015 & 0.535 \\
\hline $\mathrm{v}$ & 0.657 & 0.041 & -0.681 & -0.757 & 0.059 & -0.608 & 0.247 & -0.721 & -0.205 & 0.419 & 0.875 & 0.399 & 0.467 & 0.579 & -0.46 & 0.563 \\
\hline $\mathrm{Y}$ & 0.533 & 0.03 & -0.605 & -0.562 & -0.058 & -0.308 & 0.195 & -0.518 & 0.083 & 0.343 & 0.515 & -0.057 & -0.033 & 0.484 & -0.561 & 0.542 \\
\hline $\mathrm{Zn}$ & 0.514 & -0.274 & -0.472 & -0.505 & 0.209 & -0.387 & 0.175 & -0.28 & 0.11 & 0.404 & 0.325 & 0.675 & 0.434 & 0.364 & 0.117 & 0.344 \\
\hline $\mathrm{Zr}$ & -0.426 & 0.455 & 0.461 & 0.259 & -0.429 & 0.352 & -0.589 & 0.35 & 0.339 & -0.451 & -0.636 & 0.103 & 0.055 & -0.501 & 0.316 & -0.019 \\
\hline $\mathrm{Fe} / \mathrm{Mn}$ & -0.935 & 0.553 & 0.842 & 0.735 & -0.182 & 0.357 & -0.37 & 0.5 & -0.298 & -0.436 & -0.439 & -0.336 & -0.274 & -0.758 & -0.027 & -0.591 \\
\hline $\begin{array}{l}\text { Growth } \\
\text { rate }\end{array}$ & -0.616 & 0.33 & 0.57 & 0.519 & -0.194 & 0.554 & -0.297 & 0.489 & -0.339 & -0.233 & -0.422 & -0.116 & -0.215 & -0.794 & 0.134 & -0.368 \\
\hline & Mo & $\mathrm{Nb}$ & $\mathrm{Nd}$ & $\mathrm{Ni}$ & $\mathrm{Pb}$ & $\mathrm{Sr}$ & \multicolumn{2}{|c|}{$\mathrm{Tl}$} & \multicolumn{2}{|c|}{$\mathrm{v}$} & $\mathrm{Y}$ & $\mathrm{Zn}$ & $\mathrm{Zr}$ & $\mathrm{Fe} / \mathrm{Mn}$ & \multicolumn{2}{|c|}{ Growth Rate } \\
\hline Mn & 0.829 & 0.48 & 0.403 & 0.805 & 0.82 & 0.891 & \multicolumn{2}{|c|}{0.853} & \multicolumn{2}{|c|}{0.657} & 0.533 & 0.514 & -0.426 & -0.935 & \multicolumn{2}{|c|}{-0.616} \\
\hline $\mathrm{Fe}$ & -0.11 & -0.165 & 0.159 & -0.64 & -0.255 & -0.102 & \multirow{2}{*}{\multicolumn{2}{|c|}{$\begin{array}{l}-0.529 \\
-0.788\end{array}$}} & \multicolumn{2}{|c|}{0.041} & 0.03 & -0.274 & 0.455 & 0.553 & \multicolumn{2}{|c|}{$\begin{array}{l}0.33 \\
0.57\end{array}$} \\
\hline $\mathrm{Si}$ & -0.732 & -0.485 & -0.32 & -0.716 & -0.804 & -0.894 & & & \multirow{2}{*}{\multicolumn{2}{|c|}{$\begin{array}{l}-0.681 \\
-0.757\end{array}$}} & -0.605 & -0.472 & 0.461 & 0.842 & & \\
\hline Al & -0.855 & -0.453 & -0.526 & -0.549 & -0.759 & -0.872 & \multicolumn{2}{|c|}{-0.625} & & & -0.562 & -0.505 & 0.259 & 0.735 & & \\
\hline $\mathrm{Mg}$ & -0.053 & -0.011 & -0.236 & 0.486 & 0.177 & -0.08 & & & & & -0.058 & 0.209 & -0.429 & -0.182 & & \\
\hline $\mathrm{Na}$ & -0.552 & -0.37 & -0.26 & -0.433 & -0.624 & -0.5 & & & & & -0.308 & -0.387 & 0.352 & 0.357 & & \\
\hline $\mathrm{Ca}$ & 0.154 & 0.166 & -0.109 & 0.396 & 0.366 & 0.314 & & & & & 0.195 & 0.175 & -0.589 & -0.37 & & \\
\hline $\mathrm{K}$ & -0.701 & -0.324 & -0.447 & -0.399 & -0.68 & -0.754 & & & & & -0.518 & -0.28 & 0.35 & 0.5 & & \\
\hline Ti & 0.02 & 0.697 & 0.28 & 0.091 & 0.132 & 0.186 & & & & & 0.083 & 0.11 & 0.339 & -0.298 & & \\
\hline $\mathbf{P}$ & 0.364 & 0.108 & 0.023 & 0.395 & 0.401 & 0.435 & & & & & 0.343 & 0.404 & -0.451 & -0.436 & & \\
\hline As & 0.688 & 0.187 & 0.28 & 0.462 & 0.736 & 0.736 & & & & & 0.515 & 0.325 & -0.636 & -0.439 & & \\
\hline Ba & 0.509 & 0.329 & 0.401 & 0.206 & 0.322 & 0.404 & & & & & -0.057 & 0.675 & 0.103 & -0.336 & & \\
\hline $\mathrm{Ce}$ & 0.551 & 0.398 & 0.611 & 0.173 & 0.307 & 0.393 & & & & & -0.033 & 0.434 & 0.055 & -0.274 & & \\
\hline Co & 0.619 & 0.68 & 0.293 & 0.754 & 0.815 & 0.75 & & & & & 0.484 & 0.364 & -0.501 & -0.758 & & \\
\hline $\mathrm{Cu}$ & -0.366 & 0.042 & -0.263 & 0.073 & -0.359 & -0.42 & & & & & -0.561 & 0.117 & 0.316 & -0.027 & & \\
\hline $\mathrm{La}$ & 0.774 & 0.508 & 0.837 & 0.302 & 0.596 & 0.793 & & & & & 0.542 & 0.344 & -0.019 & -0.591 & & \\
\hline Mo & 1 & 0.247 & 0.594 & 0.568 & 0.763 & 0.871 & & & & & 0.446 & 0.52 & -0.399 & -0.702 & & \\
\hline $\mathrm{Nb}$ & 0.247 & 1 & 0.243 & 0.366 & 0.554 & 0.469 & & & & & 0.295 & 0.356 & 0.045 & -0.489 & & \\
\hline $\mathrm{Nd}$ & 0.594 & 0.243 & 1 & 0.07 & 0.293 & 0.455 & & & & & 0.298 & 0.146 & 0.125 & -0.295 & & \\
\hline $\mathrm{Ni}$ & 0.568 & 0.366 & 0.07 & 1 & 0.684 & 0.584 & & & & & 0.242 & 0.581 & -0.581 & -0.859 & & \\
\hline $\mathrm{Pb}$ & 0.763 & 0.554 & 0.293 & 0.684 & 1 & 0.866 & & & & & 0.492 & 0.515 & -0.578 & -0.71 & & \\
\hline $\mathrm{Sr}$ & 0.871 & 0.469 & 0.455 & 0.584 & 0.866 & 1 & & & & & 0.624 & 0.488 & -0.394 & -0.77 & & \\
\hline $\mathrm{Tl}$ & 0.674 & 0.554 & 0.248 & 0.844 & 0.775 & 0.709 & & & & & 0.252 & 0.572 & -0.556 & -0.84 & & \\
\hline $\mathrm{v}$ & 0.841 & 0.197 & 0.388 & 0.53 & 0.793 & 0.789 & & & & & 0.371 & 0.487 & -0.581 & -0.506 & & \\
\hline Y & 0.446 & 0.295 & 0.298 & 0.242 & 0.492 & 0.624 & & & & & 1 & 0.098 & -0.133 & -0.43 & & \\
\hline $\mathrm{Zn}$ & 0.52 & 0.356 & 0.146 & 0.581 & 0.515 & 0.488 & & & & & 0.098 & 1 & -0.192 & -0.554 & & \\
\hline $\mathrm{Zr}$ & -0.399 & 0.045 & 0.125 & -0.581 & -0.578 & -0.394 & & & & & -0.133 & -0.192 & 1 & 0.401 & & \\
\hline $\mathrm{Fe} / \mathrm{Mn}$ & -0.702 & -0.489 & -0.295 & -0.859 & -0.71 & -0.77 & & & & & -0.43 & -0.554 & 0.401 & 1 & & \\
\hline $\begin{array}{l}\text { Growth } \\
\text { rate }\end{array}$ & -0.399 & -0.595 & -0.185 & -0.586 & -0.609 & -0.511 & & & & & -0.302 & -0.207 & 0.356 & 0.579 & & \\
\hline
\end{tabular}

${ }^{\text {a }}$ Bold values represent correlations at the $99 \%$ confidence level. 


\subsection{Factor Analysis}

A factor analysis was performed for the 89 hydrogenetic macro-layers and bulk crusts. Four significant factors explain $75 \%$ of the variance in the data set (Figure 9). Factor 1 is interpreted as $\delta-\mathrm{MnO}_{2}$ and accounts for $45.2 \%$ of the variance, factor 2 as Fe-oxyhydroxides and accounts for $12.8 \%$, factor 3 as a Fe (+As) dominated phase accounting for $10.3 \%$, and factor 4 as a $\mathrm{Ti}$ phase accounting for $5.9 \%$. For each factor, elements with the highest scores are: $\delta-\mathrm{MnO}_{2}$ : Sr, Mn, Pb, Mo, Co, Tl, V, As, La, Ni, Zn, Y, P, Nb; Fe-oxyhydroxides: Zr, Ce, Fe, $\mathrm{Nd}$; $\mathrm{Fe}$ (+As) phase: negatively correlated to $\mathrm{Cu}$ and Ti; Ti phase: negatively correlated to Ba.
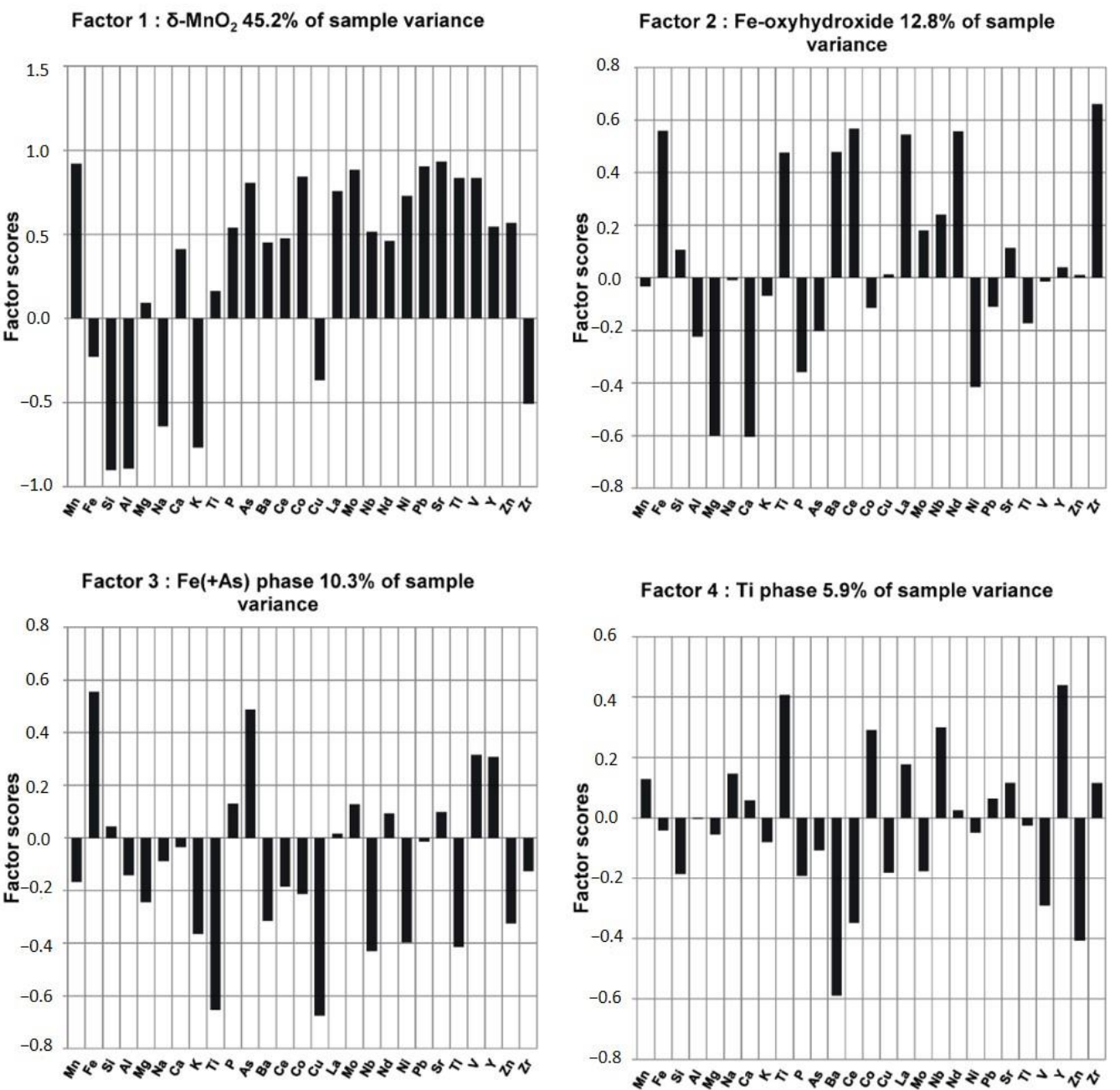

Figure 9. Histograms of factor scores for the four factors (computed for the hydrogenetic bulk and macro-layers samples, $n=89$ ).

Mineral associations and phases determined using factor analysis present important discrepancies compared to phases obtained with correlation matrices (Table 5). A dominant $\delta-\mathrm{MnO}_{2}$ phase is found, presenting associations with common Mn-associated elements $(\mathrm{Mn}, \mathrm{Ba}, \mathrm{Co}, \mathrm{Mo}, \mathrm{Ni}, \mathrm{Zn})$ and elements from Fe-oxyhydroxides ( $\mathrm{Pb}, \mathrm{As}, \mathrm{Nb}, \mathrm{Y})$, and includes elements partitioned between both groups: Tl, La, Nd, $\mathrm{Sr}$ and $\mathrm{V}$. This phase is also characterised by a strong opposition to aluminosilicate elements such as $\mathrm{Si}, \mathrm{Al}, \mathrm{Mg}, \mathrm{Na}$, $\mathrm{K}, \mathrm{Cu}$ and $\mathrm{Zr}$. The Fe-oxyhydroxides phase is different; $\mathrm{Zr}$ and $\mathrm{Ce}$ are the main elements and $\mathrm{Nd}$ is correlated to this factor. Negative correlations are found with likely biogenic related elements, $\mathrm{Ca}, \mathrm{Mg}$ and $\mathrm{Ni}$. Using factor analysis, no fluorapatite or residual biogenic phases were detected. Fe (+As) phase shows stark anti-correlations with $\mathrm{Ti}$ and $\mathrm{Cu}$, and weaker ones with Mn-associated elements. The last factor is difficult to identify because its only significant correlation is an anti-correlation with $\mathrm{Ba}$. Weaker anti-correlations with $\mathrm{Ce}$ 
and $\mathrm{Zn}$ are also found, possibly indicating an opposition to a biogenic phase composed of $\mathrm{Ba}, \mathrm{Ce}$ and $\mathrm{Zn}[1,4]$. As $\mathrm{Y}$ is already significantly correlated to $\delta-\mathrm{MnO}_{2}$, the main element positively correlated to this factor is Ti.

\section{Discussion}

According to their macroscopic features, as well as mineralogical and geochemical compositions, we can distinguish a group of hydrogenetic Fe-Mn crusts (98 of 104 samples) from a group of deposits presenting hydrothermal characteristics (six samples).

\subsection{Comparison of New Caledonia's Fe-Mn Crusts with Other Oceans Deposits}

Fe-Mn deposits are found in all oceans, covering different types of geomorphological settings and environments, reflecting a large panel of chemical compositions and morphologies. The physiography within the New Caledonian EEZ is complex and contains several ridges and seamounts where crusts are expected to be found. In order to compare New Caledonia's Fe-Mn crusts composition with crusts from elsewhere in the global ocean, Figure 10 compiles compositions of Fe-M crusts and nodules from several oceans (after $[1,76,77])$ compared to New Caledonia's Fe-Mn crusts (this study). New Caledonian crusts' concentrations were normalised to other oceans' crusts' concentrations, and presented as ratios.

The New Caledonian crusts show Fe concentrations close to that of Fe-Mn crusts from the Atlantic (0.99), Indian (0.93) and Non-Prime North Pacific (0.92) oceans, whilst crusts from the North-Pacific Prime Zone (PCZ, 1.22) and the South Pacific Ocean (1.14) exhibit enriched concentrations. Mn is higher for crusts from New Caledonia compared to the Atlantic Ocean (1.20), but lower than crusts from the CA margin (0.89), the South-Pacific (0.80), the Non-Prime North Pacific (0.74) and the PCZ (0.76) oceans. Concentrations of elements of economic interest $\mathrm{Co}$ and $\mathrm{Ni}$ are higher than in crusts of the CA margin (1.34 and 1.37, respectively) and Atlantic (1.16 and 1.20), Indian (1.27 and 1.21) and North-Pacific (only Co with 1.12) oceans, but lower than crusts from the PCZ (0.63 and 0.74) and the South-Pacific (0.68 and 0.67) oceans. Detrital elements Si and Al have higher concentrations in New Caledonia's crusts than the South-Pacific (1.30 and 1.27, respectively) and PCZ (1.52 and 1.61) oceans; higher concentrations are found in the CA margin (only Si with 0.60) and the Atlantic Ocean (only Al with 0.74), whilst the rest of the concentrations are close to that of New Caledonia's crusts (within the 0.9-1.1 range). Elements that present a strong concentration in New Caledonia's crusts compared to other crusts are $\mathrm{Pb}, \mathrm{Sr}$, V and Zn, whilst concentrations of $\mathrm{K}, \mathrm{Ba}$, and $\mathrm{Cu}$ are low in New Caledonia's crusts.

New Caledonian crusts mostly resemble crusts from the Indian and Atlantic oceans, showing a mean Fe/Mn ratio greater than 1.2 that is generally suggesting a mixed hydrogenetic and hydrothermal, or continental margin hydrogenetic origin [1]. Studies on Atlantic crusts pointed a significant enrichment in terrigenous component $(\mathrm{Fe}, \mathrm{Pb}, \mathrm{Al}$, and $\mathrm{Si}$ ) compared to the Pacific Ocean crusts due to fluvial and eolian input [78]. Similar enrichments are observed in New Caledonian crusts and could be also associated with strong terrigenous components. Low $\mathrm{K}$ concentrations could reflect the nature of terrigenous elements coming from New Caledonia since the Eocene obduction of mafic and ultramafic nappes $[28,43,44]$.

Considering the 17 hydrogenetic Fe-Mn crusts samples analysed with ICP-MS (Table 4), the mean $\Sigma$ REE in New Caledonia's crusts is 1307 ppm, whilst it is ranging between 2352 ppm and 2541 ppm for the Atlantic, Indian and North Pacific oceans (South Pacific value is closer with $1634 \mathrm{ppm}$ ) [12,70]. The mean percentage of HREE is slightly higher than the global oceans, with a value of $22 \%$ compared to $16 \%$ to $21 \%$.

Compared to polymetallic nodules from the Clarion-Clipperton Zone (CCZ), the Peru Basin and the Indian Ocean, Fe, Ca, Ti, P, As, Co, Cr, Pb, Sr, V, Y, Zr, La, Ce and a majority of REE concentrations are higher in New Caledonia's crusts. This observation confirmed that the Fe-Mn crusts are dominantly hydrogenetic, contrasting with nodules where diagenetic processes can lead to higher concentrations in $\mathrm{Cu}, \mathrm{Ni}, \mathrm{Zn}, \mathrm{Al}, \mathrm{K}$ and $\mathrm{Cd}$ [1]. 


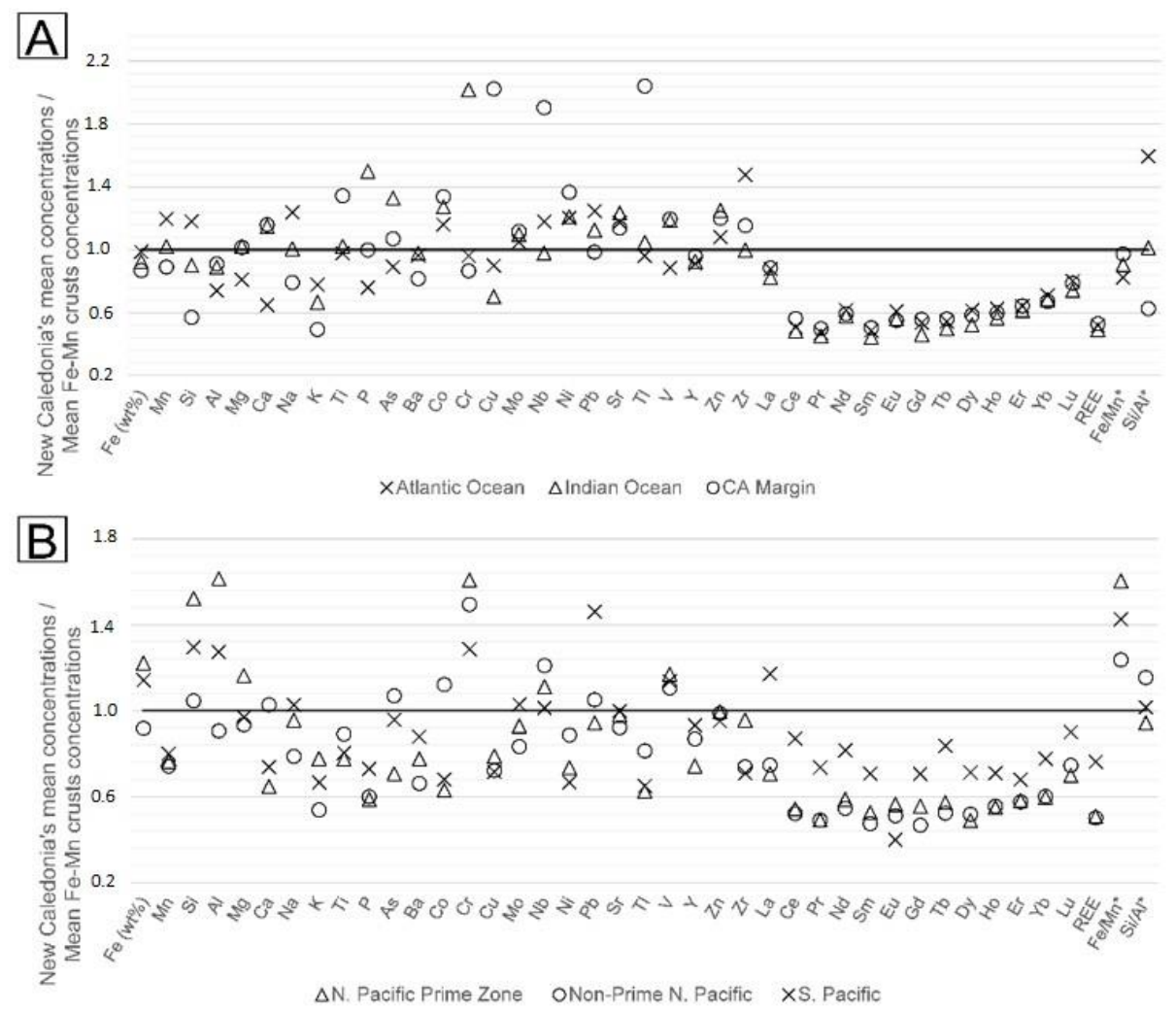

C ${ }_{150}$

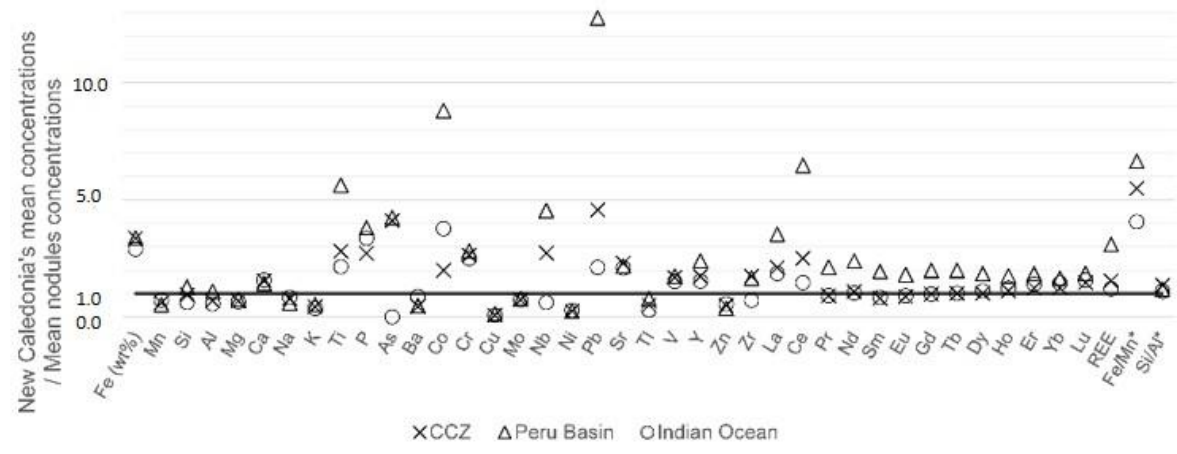

Figure 10. Element enrichment of New Caledonian crusts compared to (A) the California margin (CA), Atlantic and Indian oceans' Fe-Mn crusts, (B) the Pacific Ocean Fe-Mn crusts, and (C) polymetallic nodules from the Clarion-Clipperton Zone (CCZ), the Peru Basin and the Indian Ocean (after $[1,76,77])$. Values greater than 1 are enriched compared to other oceans crusts, whereas values lower than 1 are depleted. $\mathrm{Fe} / \mathrm{Mn}^{*}$ and $\mathrm{Si} / \mathrm{Al}^{*}$ ratios are calculated using mean ocean values.

\subsection{Crusts Chemical Changes with Water Depth}

Chemical changes in Fe-Mn crusts with water depth are a common phenomenon that has been identified in several studies [2,64,79-83]. Fe-Mn crusts selected for this study range from $430 \mathrm{~m}$ to $4677 \mathrm{~m}$ and allow us to observe changes in chemical composition with water depth (Figure 11). Non-hydrogenetic deposits are illustrated on the graphs but are not considered for this analysis. Manganese shows a large range of values at shallow depths and decreases with depth. On the contrary, Fe is more stable along the water column, with values close to $20 \%$. As a result, the Fe/Mn ratio increases from 1 to 1.5 between $1000 \mathrm{~m}$ and $3000 \mathrm{~m}$, which is phenomenon observed in several other locations [81,83]. Silicon, $\mathrm{Al}$, $\mathrm{K}$ and $\mathrm{Na}$ exhibit a net increase with depth, emphasising an increase of the aluminosilicate fraction in Fe-Mn crusts with depth. Increasing Fe, Si, Al, K and Na contents in crusts with depth are also observed in other oceans and are generally explained by an increased supply 
of detrital phases, and/or a weaker input of Mn due to the distance with the Mn-rich OMZ, whilst Fe increases with the dissolution of biogenic calcite [1,81]. Phosphorus and $\mathrm{Ca}$ in crusts decrease with water depth, possibly also representing the effect of the lysocline on carbonates and their continuous dissolution with increasing pressure at depth. Elements of economic interest $\mathrm{Ni}$ and $\mathrm{Co}$ show decreasing concentrations with depth, ranging from $7000 \mathrm{ppm}$ and $5000 \mathrm{ppm}$ at $1000 \mathrm{~m}$, respectively, to $4000 \mathrm{ppm}$ and $3000 \mathrm{ppm}$ at $3000 \mathrm{~m}$. This trend is correlated to the changing concentrations of the dissolved metals along the water column, with higher values around $1000 \mathrm{~m}$ and a marked decrease that tends to reduce with increasing depth below $2000 \mathrm{~m}$ [2]. This reflects the relationships of some trace metals with $\mathrm{Mn}$, which is explained by an enhanced supply of dissolved $\mathrm{Mn}^{2+}$ near the OMZ [1]. Other elements presenting decreasing trends with increasing water depth are $\mathrm{Mo}, \mathrm{Pb}, \mathrm{Zn}, \mathrm{As}, \mathrm{Sr}, \mathrm{Tl}$ and V. Contrarily to other metals, Cu shows a slight increase with depth, with values ranging from $500 \mathrm{ppm}$ at $1000 \mathrm{~m}$, to $1200 \mathrm{ppm}$ at $3000 \mathrm{~m}$ water depth. This increase in $\mathrm{Cu}$ content can be explained by its role in biogeochemical cycles, depleting its dissolve form in shallower waters whilst sinking organic particles progressively release it at depth [82]. Other elements such as $\mathrm{Ti}, \mathrm{Nd}, \mathrm{Ba}, \mathrm{Nb}, \mathrm{Ce}, \mathrm{Cr}, \mathrm{Y}$ and La show no particular trends, suggesting they are neither especially enriched nor depleted with depths in New Caledonian crusts.
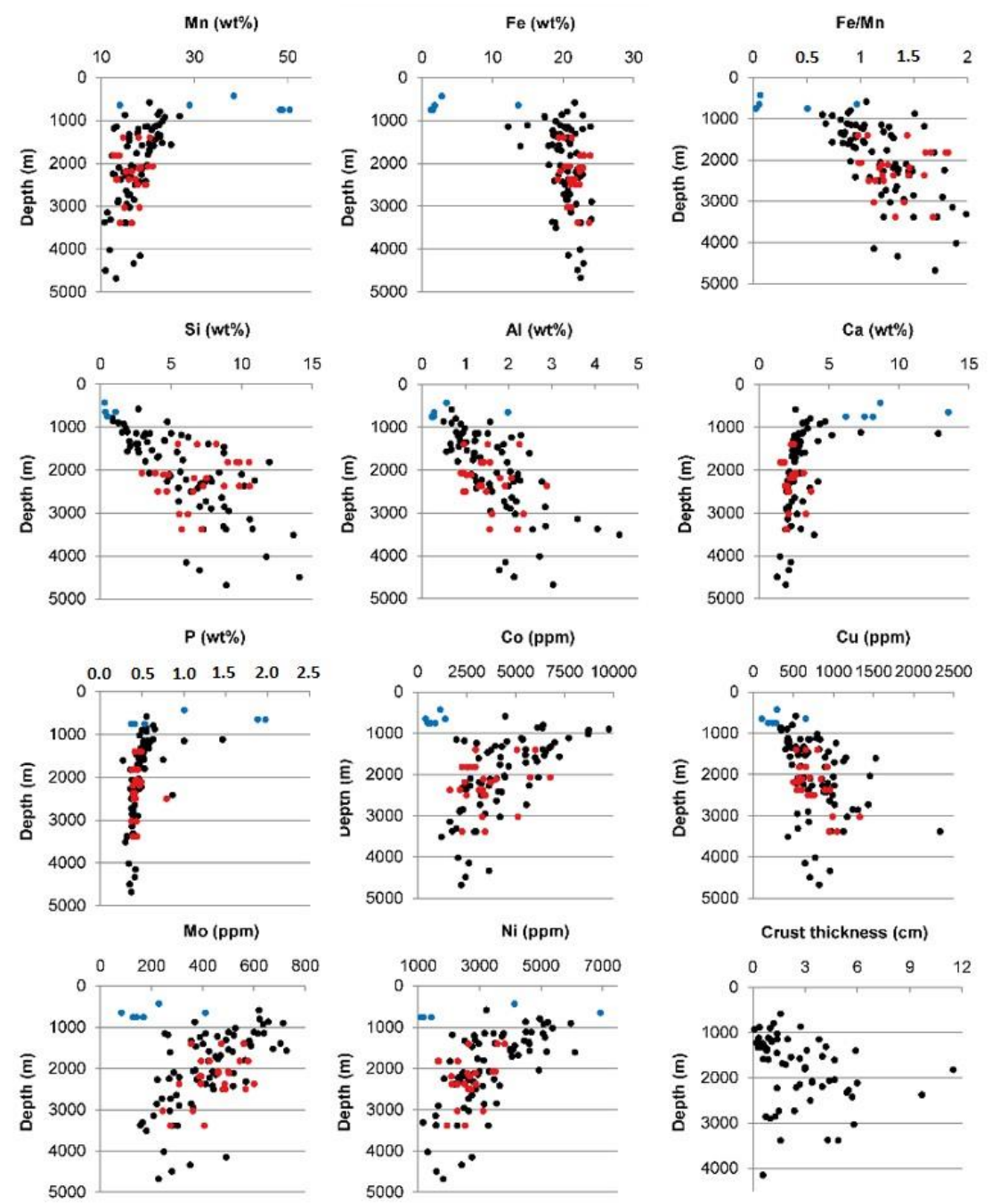

Figure 11. Repartition of selected elements with water depth. Black dots are the bulk crusts $(n=74)$, red dots are the macro-layers crusts $(n=24)$, and blue dots are the non-hydrogenetic deposits. Graph of crust thickness only considers bulk crusts with a measurable/known thicknes. 
Crust thicknesses have been measured for every sample where the right-way up was evident and for crusts with or without substrate. Final values are a mean of six measurements performed along crusts widths. The distribution of measured thicknesses highlights the presence of thicker crusts below $2000 \mathrm{~m}$ despite higher sampling density at shallower depth. The low number of valid thickness measurements for samples below $3000 \mathrm{~m}$ in our data set prevents definitive interpretation of the trend as continuously increasing, constant or decreasing. It is important to note that all samples were dredged during cruises that were not dedicated to study crusts and that sample recovery is strongly impacted by seabed and outcrop morphology. Fe-Mn crusts recovered by ROV along depth transects usually show no variation in crust thicknesses $[84,85]$. The two thickest crusts (GO327: $115 \mathrm{~mm}$, DR11Ai: $97 \mathrm{~mm}$ ) are situated respectively at $1820 \mathrm{~m}$ and $2375 \mathrm{~m}$.

\subsection{Nature of Non-Hydrogenetic Deposits}

Based on macroscopic, mineralogical and geochemical characteristics, six samples from the data set are considered as non-hydrogenetic. DW2482, DW4998D and DW4998E were dredged on the top and flanks of an Oligo-Miocene intraplate volcanic edifice on the Lord Howe Rise, part of a North/North-West oriented cluster of several seamounts (Figure 2) [19,53]. DW778D, DW778D2 and DW778B were dredged on the summit of Mount $\mathrm{K}$, a volcanic edifice of the Loyalty Ridge that is likely subduction related (Figure $2 \mathrm{~B}$ ). The presence of both amorphous and crystalline $10 \AA$ manganate ( \pm pyrolusite), and the pseudolayered structure observed at the macro and microscopic scales in the DW778 samples, are consistent with other oceans hydrothermal deposits [11-13,86]. Hydrothermal deposits originating from ascending fluids are known to form in distal parts of the venting site in several geomorphological environments: back-arc basins [12,13], arc systems [11,69,87,88], or hot spot volcanoes $[67,89,90]$. They usually present a different mineralogy compared to hydrogenetic crusts, a strong partitioning between Fe and Mn, depleted trace metal contents (however, some deposits can exhibit notable enrichments in specific trace metals), and high growth rates [64].

Such specific characteristics are found in samples DW2482 and DW4998E that present high growth rates and unusual enrichments in $\mathrm{Ni}$ (up to $0.7 \%$ ). Ni enrichment in hydrothermal deposits have been found in several places, such as the Yap volcanic arc [64], the submarine rift zones near Hawaii [91], or in the Wallis and Futuna back-arc system [9]. Same observations have also been pointed out by [19] in samples from the same group of volcanic seamounts on the Lord Howe Rise (samples DR01 were dredged from the same seamount as DW2482, DW4998D and DW4998E). In this study, Fe-Mn encrusted hyaloclastites and foraminifer-rich chalks are hydrothermally influenced, show strong $\mathrm{Mn}$ concentrations (up to $42.7 \%$ ), low Fe concentrations (down to $0.53 \%$ ), Ni enrichment (up to $0.65 \%$ ), and globally depleted Co contents. These concentrations are similar to the ones we reported for DW2482, DW4998D and DW4998E, suggesting that they could possibly share the same origin.

Trace metal enrichments in these type of deposits are controlled by several parameters, such as the volume and type of leached rocks and sediments, the precipitation of sulfides at depth, the degree of partitioning between $\mathrm{Mn}$ and Fe, the amount of mixing with seawater and the distance from the vent sites [11,92]. It is likely that these parameters have influenced the formation of these samples, as notable differences in $\mathrm{Ni}, \mathrm{Ba}, \mathrm{Zn}$ and $\mathrm{Cu}$ concentrations between close dredging sites are observed. Based only on macroscopic description and $\mathrm{XRD} / \mathrm{XRF} / \mathrm{SEM}$ analyses of these six samples, it is not possible to decipher the origin of the Ni enrichment.

\subsection{Resource Considerations}

Hydrogenetic Fe-Mn crusts can be strongly enriched in rare and critical metals, such as $\mathrm{Co}, \mathrm{Te}, \mathrm{Mo}, \mathrm{Bi}, \mathrm{Pt}, \mathrm{W}, \mathrm{Zr}, \mathrm{Nb}, \mathrm{Y}$ and $\mathrm{REE}$ [12]. These concentrations make Fe-Mn crusts potential resources for metals used in high and green technology [93]. As mentioned in Section 5.2, New Caledonian Fe-Mn crusts show typical metal compositions of deposits 
formed in the vicinity of a continental mass with moderate enrichment in metals of economic interest compared to values of PCZ and higher detrital content. Cobalt and $\mathrm{Ni}$, considered of greatest economic interest [12,71], are in the range of crusts from the Atlantic or Indian oceans, but less concentrated than in North and South-Pacific crusts. Data from this study indicates that the highest $\mathrm{Co}$ and $\mathrm{Ni}$ concentrations are located at water depth ranging from $1000 \mathrm{~m}$ to $2000 \mathrm{~m}$, whilst crust thickness tends to be the highest around $2000 \mathrm{~m}$ (Figure 11). Correlation analysis showed that $\mathrm{Co}$ and $\mathrm{Ni}$ are mostly bound to the $\delta-\mathrm{MnO}_{2}$ phase, which also displays significant correlations with elements of economic interest like $\mathrm{Mo}$ and $\mathrm{Nb}$ (see part 4.6). The $\mathrm{Co}+\mathrm{Ni}+\mathrm{Cu}(\%)$ content can reach high values in New Caledonia in sites close to the ridges and seamounts of the southern part of the EEZ. There, clusters of crust samples exhibit values reaching up to 1.62\% (Figure 12). The physiography of this area is particularly favourable to Fe-Mn crust exploration; (i) several seamounts of the Loyalty and Norfolk ridges combine acceptable exploration and mine-site parameters, such as a seamount area larger than $400 \mathrm{~km}^{2}$; (ii) water depth above $2500 \mathrm{~m}$; and (iii) large areas with slope values between $0^{\circ}$ and $20^{\circ}[2,94]$.

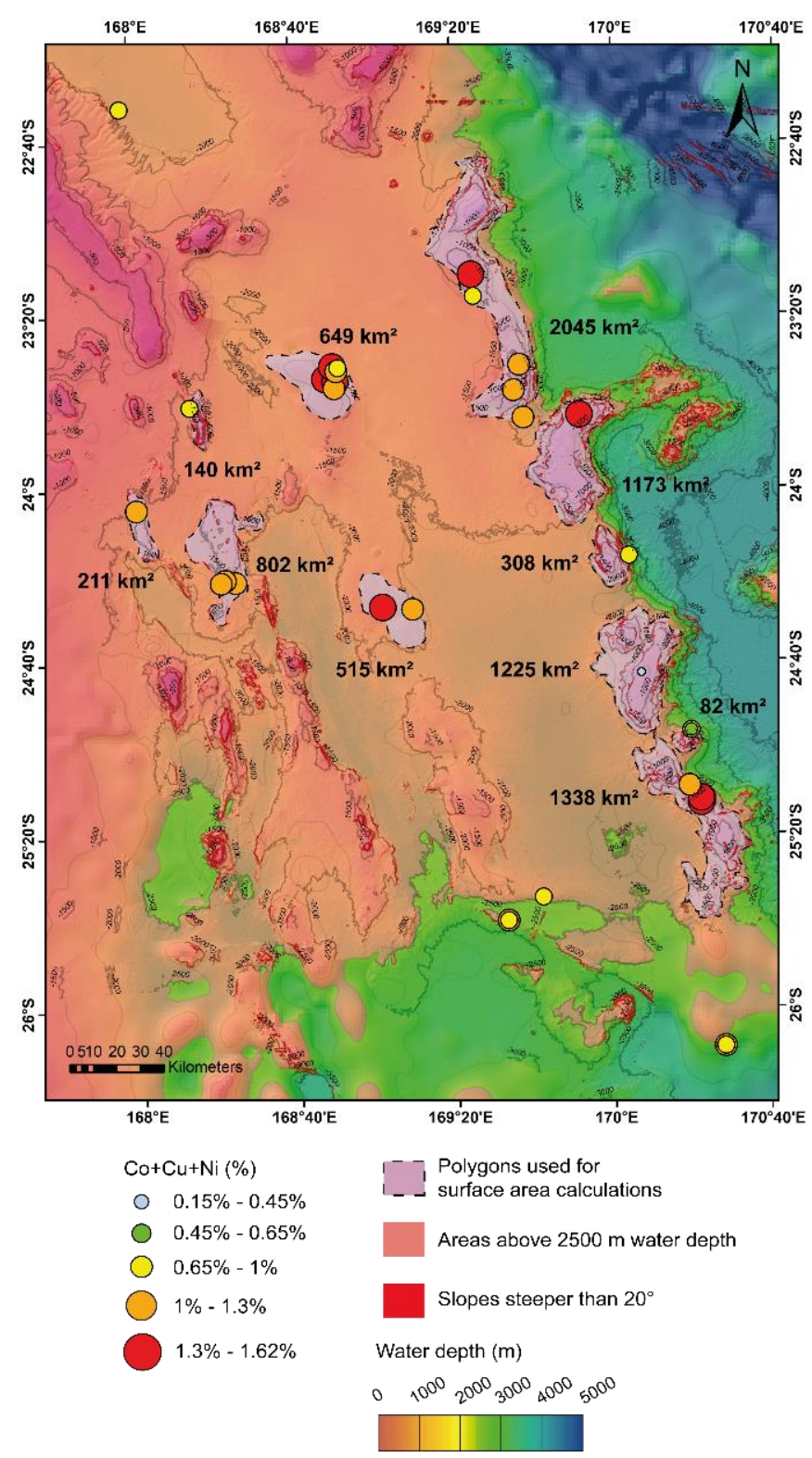

Figure 12. Map of hydrogenetic sample's $\mathrm{Co}+\mathrm{Cu}+\mathrm{Ni}(\%)$ concentration, focused on the Southern part of New Caledonia EEZ, with indications of slope values and surface area (contour lines $=500 \mathrm{~m}$ ). 
A summary of Fe-Mn crusts resource assessment is proposed in Figure 12 using criteria cited above and samples analysed in this study. Surface areas and slopes were calculated using ArcMap's 3D analyst, ArcGIS ${ }^{\circledR}$, from a $100 \mathrm{~m}$ scale bathymetric map [95]. Polygons of seamounts and ridges above $2500 \mathrm{~m}$ and presenting one or more samples were hand-drawn following bathymetric and slopes variations. This map underlines several zones of the Loyalty and Lord Howe ridges with large areas (up to $2045 \mathrm{~km}^{2}$ ), a relatively flat top (slopes $<20^{\circ}$ ) and samples with noticeable enrichment in $\mathrm{Co}+\mathrm{Ni}+\mathrm{Cu}(\%)$. However, crusts used in this study are the result of opportunistic sampling during scientific cruises of various origins (mostly biology or geology). This makes it difficult to go beyond a first-order resource assessment. To further characterise this potential, exploration should be conducted, notably through a detailed sampling strategy, seamount-scale bathymetric and backscatter mappings, and the study of physicochemical properties and motion of water masses.

\section{Summary and Conclusions}

(1) Several deposit styles were identified within the EEZ: a group of hydrogenetic crusts with chemical, textural and mineralogical characteristics similar to other hydrogenetic deposits found elsewhere in the ocean, and two groups of hydrothermal and diagenetic deposits located on the Loyalty and the Lord Howe ridges.

(2) Hydrogenetic crusts started to grow about $34 \mathrm{Ma}$ ago, at a rate of 2.2-3.1 mm/Ma, leading to a maximum crust thickness of $115 \mathrm{~mm}$.

(3) The hydrothermal/diagenetic samples from the Lord Howe Rise and the Loyalty Ridge exhibit wider chemical and mineralogical compositions (10 A manganates \pm pyrolusite), as well as a significant enrichment in Ni for two samples.

(4) New Caledonia's hydrogenetic crust compositions are in the range of typical hydrogenetic Fe-Mn crusts. The mean combined concentration of metals with high economic potential $\mathrm{Co}+\mathrm{Ni}+\mathrm{Cu}$ is $0.81 \%$, which is higher than Indian and Atlantic oceans, but lower than the Pacific Prime Crust Zone and the South Pacific Ocean. Several seamounts in the Southern part of the EEZ present clusters of $\mathrm{Co}+\mathrm{Ni}+\mathrm{Cu}$ values above $1 \%$.

(5) Further investigations will be needed to constrain more precisely the depositional settings of the hydrothermal/diagenetic samples, and the economic potential of hydrogenetic Fe-Mn crusts inside New Caledonia's EEZ.

Supplementary Materials: The following are available online at https:/ / www.mdpi.com/article / 10.3390/min12020255/s1: Table S1: Normalised to $0 \% \mathrm{H}_{2} \mathrm{O}^{-}$XRF chemical compositions of 104 Fe-Mn samples.

Author Contributions: Conceptualization, P.S. and J.C.; methodology, P.S., P.J. and E.P.; validation, J.C., P.J. and E.P.; formal analysis, P.S., P.J. and E.P.; resources, S.C., A.B. and Y.G.; writing-original draft preparation, P.S.; writing—review and editing, J.C., P.J., E.P., S.E. and M.P.; supervision, J.C., S.E. and E.P.; project administration, J.C., S.E. and E.P. All authors have read and agreed to the published version of the manuscript.

Funding: This research has been funded by a research collaboration between Ifremer and the Gouvernment of New Caledonia.

Data Availability Statement: The data presented in this study are available in the main body of the paper and in Supplementary Materials.

Acknowledgments: P.S. thanks the Direction de l'Industrie des Mines et de l'Energie de NouvelleCalédonie (DIMENC), the Agence de Développement Économique de la Nouvelle-Calédonie (ADECAL), and the Institut Français pour l'Exploitation de la Mer (IFREMER) for hosting whilst working on the manuscript. P.J. publishes with the permission of the Executive Director, British Geological Survey (UKRI). We thank three anonymous reviewers for relevant suggestions and editors for handling of this publication.

Conflicts of Interest: The authors declare no conflict of interest. 


\section{References}

1. Hein, J.; Koschinsky, A.; Bau, M.; Manheim, F.; Kang, J.-K.; Roberts, L. Cobalt-Rich Ferromanganese Crusts in the Pacific. In Handbook of Marine Mineral Deposits; CRC Press: Boca Raton, FL, USA, 2000; Volume 17, pp. 239-279.

2. Halbach, P.E.; Jahn, A.; Cherkashov, G. Marine Co-Rich Ferromanganese Crust Deposits: Description and Formation, Occurrences and Distribution, Estimated World-wide Resources. In Deep-Sea Mining; Springer International Publishing: Cham, Switzerland, 2017; pp. 65-141.

3. Koschinsky, A.; Hein, J.R. Marine Ferromanganese Encrustations: Archives of Changing Oceans. Elements 2017, 13, 177-182. [CrossRef]

4. Hein, J.; Morgenson, L.; Clague, D.; Koski, R. Cobalt-rich ferromanganese crusts from the Exclusive Economic Zone of the United States and nodules from the oceanic Pacific. In Geology and Resource Potential of the Continental Margin of Western North America and Adjacent Ocean Basins-Beaufort Sea to Baja California; Circum Pacific Council for Energy and Mineral Resources: Menlo Park, CA, USA, 1987; pp. 753-771.

5. Josso, P.; Rushton, J.; Lusty, P.; Matthews, A.; Chenery, S.; Holwell, D.; Kemp, S.J.; Murton, B. Late Cretaceous and Cenozoic paleoceanography from north-east Atlantic ferromanganese crust microstratigraphy. Mar. Geol. 2020, 422, 106122. [CrossRef]

6. Kuhn, T.; Wegorzewski, A.; Rühlemann, C.; Vink, A. Composition, Formation, and Occurrence of Polymetallic Nodules; Sharma, R., Ed.; Deep-Sea Mining; Springer: Cham, Switzerland, 2017; pp. 23-63.

7. Koschinsky, A.; Halbach, P. Sequential leaching of marine ferromanganese precipitates: Genetic implications. Geochim. Cosmochim. Acta 1995, 59, 5113-5132.

8. Koschinsky, A.; Hein, J.R. Uptake of elements from seawater by ferromanganese crusts: Solid-phase associations and seawater speciation. Mar. Geol. 2003, 198, 331-351. [CrossRef]

9. Hein, J.R.; Mizell, K.; Koschinsky, A.; Conrad, T.A. Deep-ocean mineral deposits as a source of critical metals for high- and green-technology applications: Comparison with land-based resources. Ore Geol. Rev. 2013, 51, 1-14. [CrossRef]

10. Hein, J.R.; Hsueh-Wen, Y.; Gunn, S.H.; Gibbs, A.E.; Chung-ho, W. Composition and origin of hydrothermal ironstones from central Pacific seamounts. Geochim. Cosmochim. Acta 1994, 58, 179-189.

11. Hein, J.R.; Schulz, M.S.; Dunham, R.E.; Stern, R.J.; Bloomer, S.H. Diffuse flow hydrothermal manganese mineralization along the active Mariana and southern Izu-Bonin arc system, western Pacific. J. Geophys. Res. Solid Earth 2008, 113. [CrossRef]

12. Kuhn, T.; Bostick, B.C.; Koschinsky, A.; Halbach, P.; Fendorf, S. Enrichment of Mo in hydrothermal Mn precipitates: Possible Mo sources, formation process and phase associations. Chem. Geol. 2003, 199, 29-43. [CrossRef]

13. Fitzgerald, C.E.; Gillis, K.M. Hydrothermal manganese oxide deposits from Baby Bare seamount in the Northeast Pacific Ocean. Mar. Geol. 2006, 225, 145-156. [CrossRef]

14. Pelleter, E.; Fouquet, Y.; Etoubleau, J.; Cheron, S.; Labanieh, S.; Josso, P.; Bollinger, C.; Langlade, J. Ni-Cu-Co-rich hydrothermal manganese mineralization in the Wallis and Futuna back-arc environment (SW Pacific). Ore Geol. Rev. 2017, 87, 126-146. [CrossRef]

15. Daniel, J.; Dugas, F.; Dupont, J.; Jouannic, C.; Launay, J.; Monzier, M.; Récy, J. La zone charnière Nouvelle-Calédonie-Ride de Norfolk (S.W. Pacifique): Résultats de dragages et interprétation. Cah. ORSTOM Série Géologie 1976, 8, 95-105.

16. Monzier, M.; Vallot, J. Rapport Préliminaire Concernant les Dragages Réalisés lors de la Campagne GEOSTORM 3 Sud (1975); Centre de Noumea: Nouméa, Nouvelle-Calédonie, 1983; 77p.

17. Monzier, M.; Boulin, J.; Collot, J.-Y.; Daniel, J.; Lallemand, S.; Pelletier, B.E. First results of SUBPSO I dives in the collision zone "Loyalty islands ridge/New Hebrides island arc" (South West Pacific). Comptes Rendus De L'Académie Des Sci. Paris Série II 1989, 309, 2069-2076.

18. Pichocki, C.; Hoffert, M. Characteristics of Co-rich ferromanganese nodules and crusts sampled in French Polynesia. Mar. Geol. 1987, 77, 109-119. [CrossRef]

19. Exon, N.; Quilty, P.; Lafoy, Y.; Crawford, A.J.; Auzende, J.-M. Miocene volcanic seamounts on northern Lord Howe Rise: Lithology, age and origin. Aust. J. Earth Sci. 2004, 51, 291-300. [CrossRef]

20. Richer de Forges, B. BATHUS 3 cruise. RV Alis 1993. [CrossRef]

21. Richer de Forges, B. EBISCO cruise. RV Alis 2005. [CrossRef]

22. Recy, J. EVA. Mar. Geol. 1976. Available online: https://campagnes.flotteoceanographique.fr/series/199/ (accessed on 21 July 2021 ).

23. Dubois, J.P. GEORSTOM II cruise. RV Coriolis 1974. [CrossRef]

24. Dubois, J.P. GEORSTOM III EST cruise. RV Le Noroit 1975. [CrossRef]

25. Launay, J. GEORSTOM III SUD cruise. RV Le Noroit 1975. [CrossRef]

26. Recy, J. GEORSTOM III NORD cruise. RV Le Noroit 1975. [CrossRef]

27. Collot, J.; Rouillard, P. IPOD cruise. RV Alis 2012. [CrossRef]

28. Samadi, S.; Hourdez, S. KANADEEP 1 cruise. RV Alis 2017. [CrossRef]

29. Samadi, S.; Olu, K. KANADEEP 2 cruise. $R V$ L'Atalante 2019. [CrossRef]

30. Patriat, M.; Mortimer, N. VESPA cruise. $R V$ L'Atalante 2015. [CrossRef]

31. Patriat, M.; Collot, J.; Etienne, S.; Poli, S.; Clerc, C.; Mortimer, N.; Pattier, F.; Juan, C.; Roest, W.R. New Caledonia Obducted Peridotite Nappe: Offshore Extent and Implications for Obduction and Postobduction Processes. Tectonics 2018, 37, 1077-1096. [CrossRef] 
32. Cluzel, D.; Maurizot, P.; Collot, J.; Sevin, B. An outline of the Geology of New Caledonia; from Permian-Mesozoic Southeast Gondwanaland active margin to Cenozoic obduction and supergene evolution. Episodes 2012, 35, 72-86. [CrossRef] [PubMed]

33. Collot, J.; Vendé-Leclerc, M.; Rouillard, P.; Lafoy, Y.; Géli, L. Map helps unravel complexities of the southwestern Pacific Ocean. Eos Trans. Am. Geophys. Union 2012, 93, 1-2. [CrossRef]

34. Mortimer, N.; Hauff, F.; Calvert, A.T. Continuation of the New England Orogen, Australia, beneath the Queensland Plateau and Lord Howe Rise. Aust. J. Earth Sci. 2008, 55, 195-209. [CrossRef]

35. Cluzel, D.; Adams, C.J.; Meffre, S.; Campbell, H.; Maurizot, P. Discovery of Early Cretaceous Rocks in New Caledonia: New Geochemical and U-Pb Zircon Age Constraints on the Transition from Subduction to Marginal Breakup in the Southwest Pacific. J. Geol. 2010, 118, 381-397. [CrossRef]

36. Collot, J.; Patriat, M.; Sutherland, R.; Williams, S.; Cluzel, D.; Seton, M.; Pelletier, B.; Roest, W.R.; Etienne, S.; Bordenave, A.; et al. Chapter $2^{\circ}$ Geodynamics of the SW Pacific: A brief review and relations with New Caledonian geology. Geol. Soc. Lond. Mem. 2020, 51, 13-26. [CrossRef]

37. Mortimer, N.; Campbell, H.; Tulloch, A.; King, P.; Stagpoole, V.; Wood, R.; Rattenbury, M.; Sutherland, R.; Adams, C.; Collot, J.; et al. Zealandia: Earth's Hidden Continent. GSA Today 2017, 27, 27-35. [CrossRef]

38. Maurizot, P.; Cluzel, D.; Meffre, S.; Campbell, H.J.; Collot, J.; Sevin, B. Chapter 3 Pre-Late Cretaceous basement terranes of the Gondwana active margin of New Caledonia. Geol. Soc. Lond. Mem. 2020, 51, 27-52. [CrossRef]

39. Collot, J. Geodynamic Evolution of the New Caledonia Western Offshore Domain and its Extensions Towards New Zealand. Ph.D. Thesis, Université de Bretagne occidentale, Brest, France, 2009.

40. Maurizot, P.; Bordenave, A.; Cluzel, D.; Collot, J.; Etienne, S. Chapter 4 Late Cretaceous to Eocene cover of New Caledonia: From rifting to convergence. Geol. Soc. Lond. Mem. 2020, 51, 53-91. [CrossRef]

41. Gaina, C.; Müller, D.; Royer, J.-Y.; Stock, J.; Hardebeck, J.; Symonds, P. The tectonic history of the Tasman Sea: A puzzle with 13 pieces. J. Geophys. Res. 1998, 103, 12413-12433. [CrossRef]

42. Rouillard, P.; Collot, J.; Sutherland, R.; Bache, F.; Patriat, M.; Etienne, S.; Maurizot, P. Seismic stratigraphy and paleogeographic evolution of Fairway Basin, Northern Zealandia, Southwest Pacific: From Cretaceous Gondwana breakup to Cenozoic TongaKermadec subduction. Basin Res. 2017, 29, 189-212. [CrossRef]

43. Collot, J.; Geli, L.; Lafoy, Y.; Vially, R.; Cluzel, D.; Klingelhoefer, F.; Nouze, H. Tectonic history of northern New Caledonia Basin from deep offshore seismic reflection: Relation to late Eocene obduction in New Caledonia, southwest Pacific. Tectonics 2008, 27, 1-20. [CrossRef]

44. Sutherland, R.; Collot, J.; Bache, F.; Henrys, S.; Barker, D.; Browne, G.H.; Lawrence, M.; Morgans, H.; Hollis, C.; Clowes, C.; et al. Widespread compression associated with Eocene Tonga-Kermadec subduction initiation. Geology 2017, 45, 355-358. [CrossRef]

45. Sutherland, R.; Dickens, G.; Blum, P.; Agnini, C.; Alegret, L.; Gayané, A.; Bhattacharya, J.; Aurelien, B.; Chang, L.; Collot, J.; et al. Continental-scale geographic change across Zealandia during Paleogene subduction initiation. Geology 2020, 48, 419-424. [CrossRef]

46. Cluzel, D.; Aitchison, J.C.; Picard, C. Tectonic accretion and underplating of mafic terranes in the Late Eocene intraoceanic fore-arc of New Caledonia (Southwest Pacific): Geodynamic implications. Tectonophysics 2001, 340, 23-60. [CrossRef]

47. Maurizot, P.; Cluzel, D.; Patriat, M.; Collot, J.; Iseppi, M.; Lesimple, S.; Secchiari, A.; Bosch, D.; Montanini, A.; Macera, P.; et al Chapter $5^{\circ}$ The Eocene Subduction-Obduction Complex of New Caledonia. Geol. Soc. Lond. Mem. 2020, 51, 93-130. [CrossRef]

48. Maurizot, P.; Collot, J.; Cluzel, D.; Patriat, M. Chapter $6^{\circ}$ The Loyalty Islands and Ridge, New Caledonia. Geol. Soc. Lond. Mem. 2020, 51, 131-145. [CrossRef]

49. Hackney, R.; Sutherland, R.; Collot, J. Rifting and subduction initiation history of the New Caledonia Trough, southwest Pacific, constrained by process-oriented gravity models. Geophys. J. Int. 2012, 189, 1293-1305. [CrossRef]

50. Collot, J.; Patriat, M.; Etienne, S.; Rouillard, P.; Soetaert, F.; Juan, C.; Marcaillou, B.; Palazzin, G.; Clerc, C.; Maurizot, P.; et al. Deepwater fold-and-thrust belt along New Caledonia's western margin: Relation to post-obduction vertical motions. Tectonics 2017, 36, 2108-2122. [CrossRef]

51. Sdrolias, M.; Muller, R.D.; Gaina, C.; Hillis, R.R.; Müller, R.D. Tectonic evolution of the southwest Pacific using constraints from backarc basins. In Evolution and Dynamics of the Australian Plate; Geological Society of America: Boulder, CO, USA, 2003 ; Volume 372.

52. McDougall, I.; Embleton, B.J.J.; Stone, D.B. Origin and evolution of Lord Howe Island, Southwest Pacific Ocean. J. Geol. Soc. Aust. 1981, 28, 155-176. [CrossRef]

53. Van de Beuque, S.; Auzende, J.M.; Lafoy, Y.; Missègue, F. Tectonique et volcanisme tertiaire sur la ride de Lord Howe (Sud-Ouest Pacifique) = Tertiary tectonic and volcanism on the Lord Howe Rise (South West Pacific). Comptes Rendus De L'académie Des Sci. De Paris.Série 2a Sci. De La Terre Et Des Planètes 1998, 326, 663-669.

54. Mortimer, N.; Scott, J. Volcanoes of Zealandia and the Southwest Pacific. N. Z. J. Geol. Geophys. 2020, 63, 1-7. [CrossRef]

55. Tournadour, E.; Jorry, S.J.; Etienne, S.; Collot, J.; Patriat, M.; BouDagher-Fadel, M.K.; Fournier, F.; Pelletier, B.; Le Roy, P.; Jouet, G.; et al. Neogene to Quaternary evolution of carbonate and mixed carbonate-siliciclastic systems along New Caledonia's eastern margin (SW Pacific). Mar. Geol. 2021, 438, 106524. [CrossRef]

56. Etienne, S.; Roy, P.; Tournadour, E.; Roest, W.; Jorry, S.; Collot, J.; Patriat, M.; Largeau, M.; Roger, J.; Clerc, C.; et al. Large-scale margin collapses along a partly drowned, isolated carbonate platform (Lansdowne Bank, SW Pacific Ocean). Mar. Geol. 2021, 436, 106477. [CrossRef] 
57. Pelletier, B.; Auzende, J.-M. Geometry and structure of the Vitiaz Trench Lineament (SW Pacific). Mar. Geophys. Res. 1996, 18, 305-335. [CrossRef]

58. Sevin, B.; Maurizot, P.; Cluzel, D.; Tournadour, E.; Etienne, S.; Folcher, N.; Jeanpert, J.; Collot, J.; Iseppi, M.; Meffre, S.; et al. Chapter 7 Post-obduction evolution of New Caledonia. Geol. Soc. Lond. Mem. 2020, 51, 147-188. [CrossRef]

59. Dubois, J.; Launay, J.; Recy, J. Uplift movements in New Caledonia-Loyalty Islands area and their plate tectonics interpretation. Tectonophysics 1974, 24, 133-150. [CrossRef]

60. Jochum, K.P.; Nohl, U.; Herwig, K.; Lammel, E.; Stoll, B.; Hofmann, A.W. GeoReM: A New Geochemical Database for Reference Materials and Isotopic Standards. Geostand. Geoanalytical Res. 2005, 29, 333-338. [CrossRef]

61. Barrat, J.A.; Keller, F.; Amossé, J.; Taylor, R.N.; Nesbitt, R.W.; Hirata, T. Determination of rare earth elements in sixteen silicate reference samples by ICP-MS after Tm addition and ion exchange separation. Geostand. Newsl. 1996, 20, 133-139. [CrossRef]

62. Charles, C.; Barrat, J.A.; Pelleter, E. Trace element determinations in Fe-Mn oxides by high resolution ICP-MS after Tm addition. Talanta 2021, 233, 122446. [CrossRef] [PubMed]

63. Halbach, P.; Puteanus, D. The influence of the carbonate dissolution rate on the growth and composition of Co-rich ferromanganese crusts from Central Pacific seamount areas. Earth Planet. Sci. Lett. 1984, 68, 73-87. [CrossRef]

64. Puteanus, D.; Halbach, P. Correlation of Co concentration and growth rat-A method for age determination of ferromanganese crusts. Chem. Geol. 1988, 69, 73-85. [CrossRef]

65. Koschinsky, A.; Stascheit, A.; Bau, M.; Halbach, P. Effects of phosphatization on the geochemical and mineralogical composition of marine ferromanganese crusts. Geochim. Cosmochim. Acta 1997, 61, 4079-4094. [CrossRef]

66. Manheim, F.T.; Lane-Bostwick, C.M. Cobalt in ferromanganese crusts as a monitor of hydrothermal discharge on the Pacific sea floor. Nature 1988, 335, 59-62. [CrossRef]

67. Hein, J.R.; Ahn, J.-h.; Wong, J.-C.; Kang, J.-K.; Smith, V.K.; Yoon, S.H.; D’angelo, W.M.; Yoo, S.-O.; Gibbs, A.E.; Kim, H.-J.; et al. Geology, Geophysics, Geochemistry, and Deep-Sea Mineral Deposits, Federated States of Micronesia; KORDI-USGS R.V. Farnella Cruise F11-90-CP; US Department of Interior: Washington, DC, USA, 1992.

68. Hein, J.R.; Koschinsky, A.; Halbach, P.; Manheim, F.T.; Bau, M.; Kang, J.K.; Lubick, N. Iron and manganese oxide mineralization in the Pacific. Geol. Soc. Spec. Publ. 1997, 119, 123-138. [CrossRef]

69. Usui, A.; Yuasa, M.; Yokota, S.; Nohara, M.; Nishimura, A.; Murakami, F. Submarine hydrothermal manganese deposits from the Ogasawara (Bonin) Arc, off the Japan Islands. Mar. Geol. 1986, 73, 311-322. [CrossRef]

70. Enrico, B.; Tom, K.; Harold, R. Classification and Genesis of Submarine Iron-Manganese Deposits. In Ferromanganese Deposits on the Ocean Floor; Horn, D., Ed.; National Science Foundation: Washington, DC, USA, 1972; pp. 149-165.

71. Hein, J.R.; Conrad, T.A.; Frank, M.; Christl, M.; Sager, W.W. Copper-nickel-rich, amalgamated ferromanganese crust-nodule deposits from Shatsky Rise, NW Pacific. Geochem. Geophys. Geosyst. 2012, 13. [CrossRef]

72. Josso, P.; Pelleter, E.; Pourret, O.; Fouquet, Y.; Etoubleau, J.; Cheron, S.; Bollinger, C. A new discrimination scheme for oceanic ferromanganese deposits using high field strength and rare earth elements. Ore Geol. Rev. 2017, 87, 3-15. [CrossRef]

73. Bau, M.; Schmidt, K.; Koschinsky, A.; Hein, J.; Kuhn, T.; Usui, A. Discriminating between different genetic types of marine ferro-manganese crusts and nodules based on rare earth elements and yttrium. Chem. Geol. 2014, 381, 1-9. [CrossRef]

74. Taylor, S.R.; McLennan, S.M. The continental crust: Its composition and evolution: An examination of the geochemical record preserved in sedimentary rocks. Philos. Trans. R. Soc. London. Ser. A Math. Phys. Sci. 1981, 301, 381-399.

75. Hein, J.R.; Konstantinova, N.; Mikesell, M.; Mizell, K.; Fitzsimmons, J.N.; Lam, P.J.; Jensen, L.T.; Xiang, Y.; Gartman, A.; Cherkashov, G.; et al. Arctic Deep Water Ferromanganese-Oxide Deposits Reflect the Unique Characteristics of the Arctic Ocean. Geochem. Geophys. Geosyst. 2017, 18, 3771-3800. [CrossRef]

76. Hein, J.; Koschinsky, A. Deep-ocean ferromanganese crusts and nodules. In Geochemistry of Mineral. Deposits: Treatise of Geochemistry, 2nd ed.; Elsevier: Amsterdam, The Netherlands, 2014; Volume 13, pp. 273-291.

77. Conrad, T.; Hein, J.R.; Paytan, A.; Clague, D.A. Formation of Fe-Mn crusts within a continental margin environment. Ore Geol. Rev. 2017, 87, 25-40. [CrossRef]

78. Muiños, S.B.; Hein, J.R.; Frank, M.; Monteiro, J.H.; Gaspar, L.; Conrad, T.; Pereira, H.G.; Abrantes, F. Deep-sea Fe-Mn Crusts from the Northeast Atlantic Ocean: Composition and Resource Considerations. Mar. Georesources Geotechnol. 2013, 31, 40-70. [CrossRef]

79. Mizell, K.; Hein, J.R.; Lam, P.J.; Koppers, A.A.P.; Staudigel, H. Geographic and oceanographic influences on ferromanganese crust composition along a Pacific Ocean meridional transect, 14N to 14S. Geochem. Geophys. Geosyst. 2019, 21, e2019GC008716.

80. Benites, M.; Hein, J.R.; Mizell, K.; Blackburn, T.; Jovane, L. Genesis and Evolution of Ferromanganese Crusts from the Summit of Rio Grande Rise, Southwest Atlantic Ocean. Minerals 2020, 10, 349. [CrossRef]

81. Aplin, A.C.; Cronan, D.S. Ferromanganese oxide deposits from the Central Pacific Ocean, II. Nodules and associated sediments. Geochim. Cosmochim. Acta 1985, 49, 437-451. [CrossRef]

82. Josso, P.; Lusty, P.; Chenery, S.; Murton, B. Controls on metal enrichment in ferromanganese crusts: Temporal changes in oceanic metal flux or phosphatisation? Geochim. Cosmochim. Acta 2021, 308, 60-74. [CrossRef]

83. Verlaan, P.A.; Cronan, D.S. Origin and variability of resource-grade marine ferromanganese nodules and crusts in the Pacific Ocean: A review of biogeochemical and physical controls. Geochemistry 2021, in press. [CrossRef] 
84. Usui, A.; Nishi, K.; Sato, H.; Nakasato, Y.; Thornton, B.; Kashiwabara, T.; Tokumaru, A.; Sakaguchi, A.; Yamaoka, K.; Kato, S.; et al. Continuous growth of hydrogenetic ferromanganese crusts since 17Myr ago on Takuyo-Daigo Seamount, NW Pacific, at water depths of 800-5500 m. Ore Geol. Rev. 2017, 87, 71-87. [CrossRef]

85. Yeo, I.A.; Howarth, S.A.; Spearman, J.; Cooper, A.; Crossouard, N.; Taylor, J.; Turnbull, M.; Murton, B.J. Distribution of and hydrographic controls on ferromanganese crusts: Tropic Seamount, Atlantic. Ore Geol. Rev. 2019, 114, 103131. [CrossRef]

86. Astakhova, N.V.; Lopatnikov, E.A. Composition and parageneses of massive pyrolusite from the deep-water basin of the Sea of Japan. Russ. Geol. Geophys. 2016, 57, 1465-1476. [CrossRef]

87. Cronan, D.S.; Glasby, G.P.; Moorby, S.A.; Thomson, J.; Knedler, K.E.; McDougall, J.C. A submarine hydrothermal manganese deposit from the south-west Pacific island arc. Nature 1982, 298, 456-458. [CrossRef]

88. Goto, K.T.; Shimoda, G.; Anbar, A.D.; Gordon, G.W.; Harigane, Y.; Senda, R.; Suzuki, K. Molybdenum isotopes in hydrothermal manganese crust from the Ryukyu arc system: Implications for the source of molybdenum. Mar. Geol. 2015, 369, 91-99. [CrossRef]

89. Hodkinson, R.A.; Stoffers, P.; Scholten, J.; Cronan, D.S.; Jeschke, G.; Rogers, T.D.S. Geochemistry of hydrothermal manganese deposits from the Pitcairn Island hotspot, southeastern Pacific. Geochim. Cosmochim. Acta 1994, 58, 5011-5029. [CrossRef]

90. Glasby, G.P.; Stüben, D.; Jeschke, G.; Stoffers, P.; Garbe-Schönberg, C.D. A model for the formation of hydrothermal manganese crusts from the Pitcairn Island hotspot. Geochim. Cosmochim. Acta 1997, 61, 4583-4597.

91. Hein, J.R.; Gibbs, A.E.; Clague, D.A.; Torresan, M. Hydrothermal mineralization along submarine rift zones, Hawaii. Marine Georesources Geotechnol. 1996, 14, 177-203. [CrossRef]

92. Petersen, S.; Krätschell, A.; Augustin, N.; Jamieson, J.; Hein, J.R.; Hannington, M.D. News from the seabed-Geological characteristics and resource potential of deep-sea mineral resources. Mar. Policy 2016, 70, 175-187. [CrossRef]

93. Koschinsky, A.; Hein, J.; Schmidt, K.; Alexander, B.; Bau, M. Rare and Valuable Metals for High-Tech Applications Found in Marine Ferromanganese Nodules and Crusts: Relationships to Genetic Endmembers; Abstract volume of 39th Underwater Mining Institute; Underwater Mining Institute: Gelendzhik, Russia, 2010; pp. 1-13.

94. Hein, J.R.; Conrad, T.A.; Dunham, R.E. Seamount Characteristics and Mine-Site Model Applied to Exploration- and MiningLease-Block Selection for Cobalt-Rich Ferromanganese Crusts. Mar. Georesources Geotechnol. 2009, 27, 160-176. [CrossRef]

95. Juffroy, F. Atlas Bathymétrique de la Nouvelle-Calédonie. Rapports du Service de la Géomatique et de la Télédéction du Gouvernement de la Nouvelle-Calédonie. 2009. Available online: https:/ / www.zoneco.nc/resultats-thematiques/environnementhauturier/mise-jour-de-latlas-bathymetrique-de-la-nouvelle (accessed on 17 August 2020). 